\title{
A EXPANSÃO URBANA NO PLANALTO DE CAMPOS DO JORDÃO. DIAGNÓSTICO GEOMORFOLÓGICO PARA FINS DE PLANEJAMENTO
}

\author{
May Christine MODENESI-GAUTTIERI \\ Silvio Takashi HIRUMA
}

\begin{abstract}
RESUMO
Parte do bloco principal da serra da Mantiqueira, o planalto de Campos do Jordão sofreu nas últimas décadas o impacto de uma expansão urbana contínua e desordenada, que aumentou as condições naturais de instabilidade próprias do planalto. A evolução quaternária sob climas de altitude deu origem ao sistema de paisagem atual, o geossistema dos altos campos, caracterizado por estrutura em equilíbrio precário, extremamente vulnerável ao uso inadequado do solo e a riscos ambientais urbanos. Num relevo acentuado como o do planalto, com encostas íngremes, o conhecimento das características geomorfológicas do sítio urbano é da maior importância para planejamento do desenvolvimento urbano e de interferências deliberadas no espaço natural. O mapeamento da evolução urbana $(1973,1982,2000)$ evidencia de forma nítida a intensificação do crescimento urbano nas últimas décadas e seus efeitos na descaracterização do mosaico original da vegetação. Mapeamento geomorfológico de detalhe (1:8000) foi realizado por amostragem em três áreas do vale do Capivari/Sapucaí-Guaçu, com base em trabalhos de campo e interpretação de fotos aéreas e imagens de satélite. Os compartimentos identificados anteriormente nos altos campos do planalto, como unidades dinâmicas da paisagem, caracterizadas por formas, materiais, solos, vegetação e processos próprios, constituíram a base do diagnóstico geomorfológico. Dez unidades diagnóstico foram definidas, cada uma com aptidões específicas quanto aos riscos associados ao desenvolvimento urbano. Essas unidades foram finalmente agrupadas em três classes, de acordo com a vulnerabilidade aos processos erosivos e adequação à ocupação.
\end{abstract}

Palavras-chave: diagnóstico geomorfológico, uso do solo, expansão urbana, altos campos, planalto tropical, Campos do Jordão

\section{ABSTRACT}

Part of the main block of the Serra da Mantiqueira, the Campos do Jordão Plateau has been exposed in recent decades to the pressures of a continuous and desorderly urban expansion, which increased the inherent unstable natural conditions of the tropical plateau. Quaternary evolution under high altitude (up to 2050m) conditions developed a tropical montane landscape system, the altos campos geosystem, characterized by a structure in precarious equilibrium, extremely vulnerable to inadequate land use and prone to urban environmental hazards. Knowledge of the geomorphical characteristics of the site is of the utmost importance for planning urban development and deliberate interferences in the steep high relief of the plateau. Mapping of urban evolution (1973, 1982, 2000) clearly shows the intensification of urban growth in the last decades and its effects in the decharacterization of the original vegetation mosaic. Detailed geomorphological mapping (1:8000) of three sampling areas in the more intensively urbanized Capivari/MogiGuaçu Valley was based on field work and the interpretation of aerophoto and satellite images. The geomorphological compartments identified in previous investigations at the altos campos as dynamic units characterized by specific landforms, materials, soils, vegetation and processes, constitute the basis of the diagnosis. Ten diagnostic units were defined, each one with specific aptitudes in relation 
to risks associated with urban development. These unities were finally ranked in three classes according to the vulnerability to erosive processes and fitness to urban development.

Keywords: geomorphological diagnosis, land use, urban expansion, altos campos, tropical plateau, Campos do Jordão.

\section{INTRODUÇÃO}

O planalto de Campos do Jordão é um planalto cristalino em bloco, alçado (ALMEIDA 1976) a mais de $2000 \mathrm{~m}$ de altitude e limitado por escarpas abruptas que se erguem, aproximadamente, $1500 \mathrm{~m}$ sobre as colinas do médio vale do Paraíba (Figura 1). No planalto afloram terrenos cristalinos da Província Mantiqueira (HASUI \& OLIVEIRA 1984), representados por gnaisses, migmatitos, granitos, xistos, quartzitos, calcários, calciossilicáticas e anfibolitos (HASUI et al. 1978, CAVALCANTE et al. 1979, MORAIS et al. 1998). Na bacia do Alto Sapucaí Guaçu predominam rochas gnáissicas, orientadas a NE-SW e ENEWSW, com mergulhos superiores a $50^{\circ}$, por vezes subverticais. Nos morros de altitude inferior a 1710/40m ocorrem biotita gnaisses finamente bandados com intercalações de quartzitos, anfibolitos e biotita xistos. Acima de $1800 \mathrm{~m}$, ao sul do ribeirão Capivari, afloram gnaisses, localmente com bandamento menos definido (gnaisses graníticos), e rochas granitóides; ao norte, ocor- rem gnaisses bandados e, com maior freqüência, muscovita quartzitos.

O clima do planalto é caracterizado (MODENESI 1988a) por temperaturas médias anuais de $14,3^{\circ} \mathrm{C}(1973 / 1978)$ e precipitação anual entre 1205 e 2800mm, em Capivari. Dados de 40 anos de observação mostram que a ocorrência de geadas é freqüente no inverno, variando de 9 a 70 dias/ano. Concentração de $80 \%$ das chuvas no período outubro-março e incidência de até 6 meses com porcentagens de precipitação inferiores a $2 \%$ permitem reconhecer uma estação mais seca. É interessante lembrar que as vertentes do planalto apresentam assimetria ambiental caracterizada por encostas ensolaradas e relativamente secas na face norte e encostas sombrias e úmidas na face sul-sudeste. Esta assimetria, frequente em áreas montanhosas, é acentuada em Campos do Jordão pela exposição direta da face sul às frentes polares, principais responsáveis pelas chuvas na região (MONTEIRO 1964, 1969; CONTI 1975).

A evolução quaternária sob climas de altitude deu origem ao sistema de paisagem atual, o

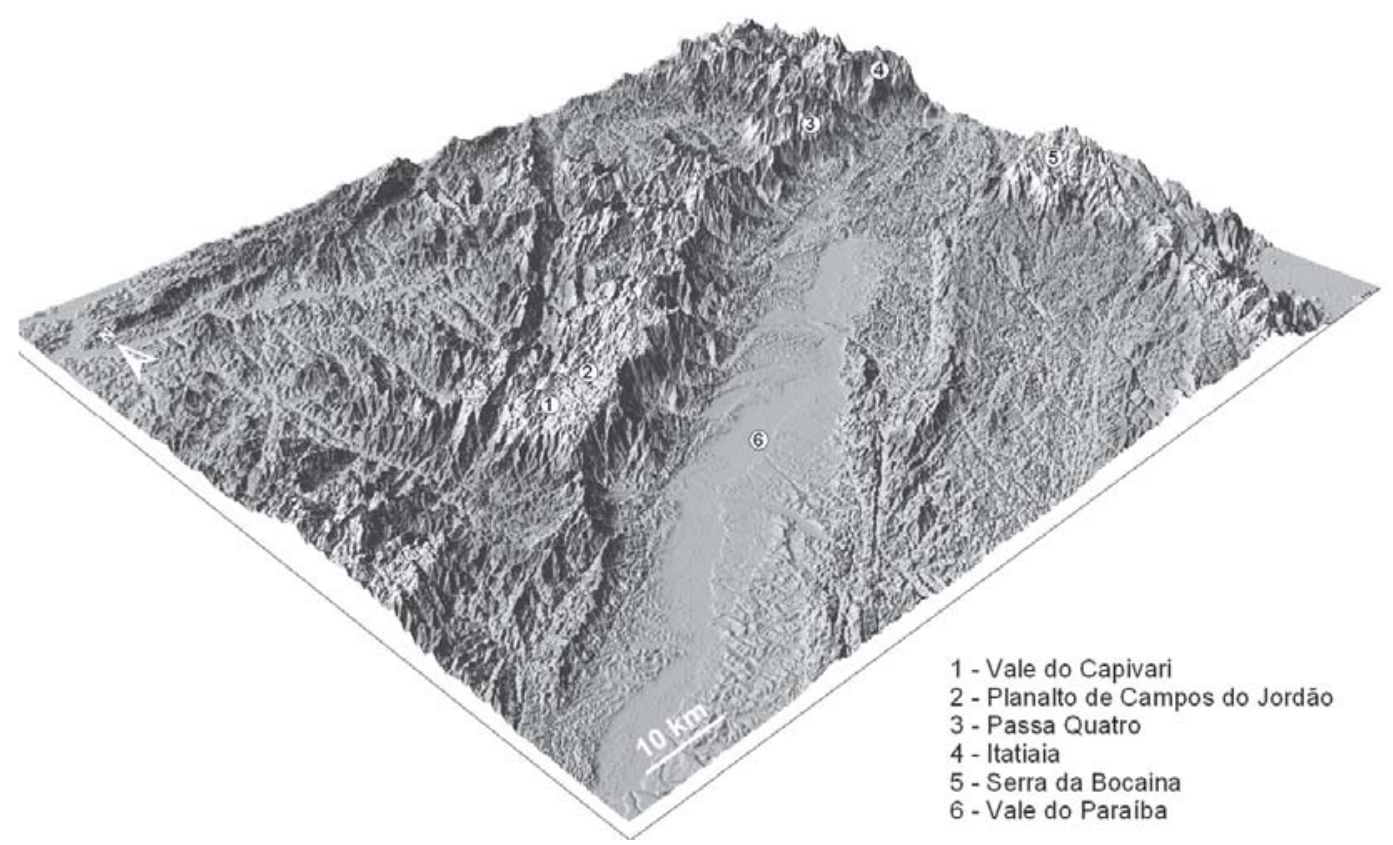

FIGURA 1 - O planalto de Campos do Jordão e a compartimentação regional. 
geossistema dos altos campos (MODENESI 1988a), singular em área tropical e bem definido nas porções mais elevadas do planalto. Paisagem típica do topo das serras da Mantiqueira (campos do Jordão e do ribeirão Fundo, Monte Verde e Itatiaia) e da Bocaina, os altos campos constituem um enclave acima dos mares de morros (AB'SÁBER 1966). O sistema de montanha tropical, caracterizado por estrutura em equilíbrio instável e extremamente vulnerável ao uso inadequado do solo, esteve exposto nas últimas décadas a intensos fenômenos de degradação da paisagem. O impacto de uma urbanização desordenada, com uso inadequado dos espaços naturais e ocupação de áreas instáveis, deu origem a problemas geoecológicos de conseqüências catastróficas. A desestabilização das vertentes foi acelerada, principalmente por processos de movimentos de massa.
O entendimento da evolução da paisagem e da combinação dos fatos geomorfológicos nela envolvidos é importante para o tratamento de problemas ambientais e para o planejamento de intervenções deliberadas nos espaços naturais. O reconhecimento das características geomorfológicas do sítio urbano permite identificar fatores favoráveis ou desfavoráveis à sua ocupação, limitações e possibilidades de uso dos solos, susceptibilidade potencial à erosão, sendo portanto essencial para a definição das áreas de preservação, de uso restrito e de ocupação urbana. Este trabalho tem por objetivo apresentar uma classificação geomorfológica de aptidão para desenvolvimento urbano, que possa servir à preservação dos recursos naturais e à reordenação da ocupação do planalto. A área escolhida para estudo foi o vale do Capivari /SapucaíGuaçu (Figuras 1 e 2), onde pressão da expansão

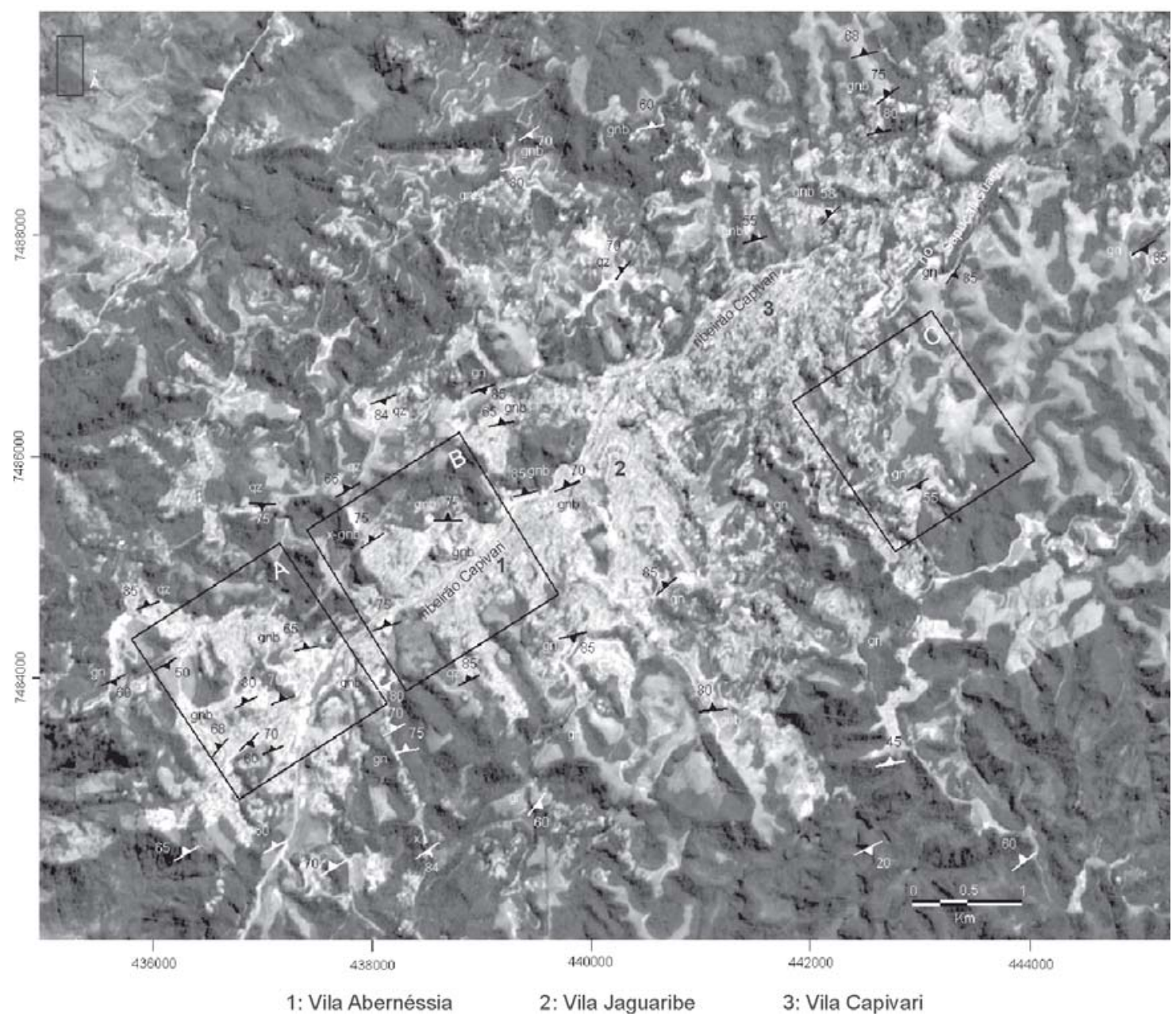

FIGURA 2 - As áreas de amostragem (A, B, C) no vale do Capivari/Sapucaí-Guaçu. Mosaico típico de distribuição da vegetação no geossistema dos altos campos. Litologia $(\mathrm{qz}=$ quartzito, $\mathrm{x}=\mathrm{xisto}, \mathrm{gn}=$ gnaisse granítico, gnb = gnaisse bandado, gr = granito) e foliações metamórficas. 
urbana e vulnerabilidade a riscos ambientais são maiores e onde já ocorreram graves desastres, por exemplo, em Vila Albertina (1972) e Vila Abernéssia (1998).

Numerosos estudos geomorfológicos efetuados nos altos campos da Mantiqueira nos últimos vinte anos permitiram acumular conhecimentos sobre a compartimentação e formas de relevo, formações superficiais, relações intemperismomorfogênese, morfotectônica, processos geomórficos e evolução quaternária dos planaltos de Campos do Jordão e Itatiaia (MODENESI 1980, 1983, 1988a, 1988b, 1992; MODENESI et al. 1982; DE PLOEY et al. 1983; MODENESI \& MELHEM 1992; MODENESI \& TOLEDO 1993, 1996; MODENESIGAUTTIERI 1996, 2000; MODENESI-GAUTTIERI \& NUNES 1998; HIRUMA 1999; HIRUMA et al. 2001; MODENESI-GAUTTIERI et al. 2002), úteis para o tratamento dos problemas ambientais dos altos planaltos do Brasil de Sudeste. No caso de Campos do Jordão, estes estudos fornecem dados básicos que podem ser aproveitados para mapeamento geomorfológico e classificação do terreno da área do Alto Sapucaí-Guaçu.

\section{METODOLOGIA}

A cartografia geomorfológica constitui o instrumento adequado para reunir e apresentar as características geomorfológicas de uma área, entretanto, cartas para aplicação prática devem ser simples e incluir apenas informações relevantes para seu fim específico (TRICART 1965, VERSTAPPEN 1983, HART 1986). Tais critérios orientaram a organização de um documento pragmático (Figuras $28,29,30$ ), adaptado aos propósitos de classificação e avaliação da paisagem para tratamento de problemas de reordenação do espaço natural e urbano.

Modelos digitais de terreno e cartas auxiliares de hipsometria, declividade (Figura 3) e orientação de vertentes foram elaborados, a partir de cartas topográficas digitalizadas na escala 1:10.000 (Projeto Macro-Eixo, Terrafoto S.A./SEP, 1977/78), para a área situada ao longo do vale do ribeirão Capivari, com cerca de $8 \mathrm{~km}$ de extensão e 6km de largura, abrangendo os núcleos urbanos de Abernéssia, Jaguaribe e Capivari. A existência de sucessivos recobrimentos aerofotogramétricos e imagens de satélite permitiu mapear a evolução da expansão urbana e observar os seus efeitos sobre o quadro natural dos altos campos. Foram mapeados três momentos da evolução urbana, os dois primeiros (1973 e 1982) utilizan- do fotos aéreas nas escalas 1:25.000 e 1:8000, e o terceiro (2000), uma imagem de satélite de alta resolução (IKONOS). Loteamentos pouco ocupados foram excluídos da mancha urbana.

Dados de pesquisas anteriores sobre o planalto de Campos do Jordão foram atualizados e complementados pelo levantamento geológicogeomorfológico de detalhe da área de estudo. A interpretação das imagens de satélite e fotos aéreas foi feita de forma integrada com os trabalhos de campo e a elaboração de legenda apropriada ao registro de formas, materiais e processos geomorfológicos.

Os mapeamentos geomorfológicos básico e de diagnóstico foram realizados na escala 1:8000 (recobrimento aerofotogramétrico Terrafoto S/A, 1982) por amostragem em três áreas (Figuras 2 e 4), duas delas escolhidas por apresentarem os problemas ambientais mais comuns no vale do Capivari (áreas A e B) e, a terceira, por ainda preservar o mosaico natural dos altos campos (área C). A escala escolhida (1:8000) é adequada à aplicação em trabalhos de reordenação urbana e zoneamento de risco (VERSTAPPEN 1983) e à representação dos fatos geomorfológicos relacionados aos problemas em foco. A compartimentação geomorfológica serviu de base à definição de unidades diagnóstico com aptidões específicas quanto aos riscos associados ao desenvolvimento urbano.

\section{O SISTEMA DE PAISAGEM DOS ALTOS CAMPOS}

O retrabalhamento quaternário do planalto de Campos do Jordão, comandado por níveis de base locais, deu origem ao seu fracionamento em duas unidades espaciais, diferenciadas não apenas pelas características morfológicas mas por um verdadeiro sistema de paisagem, com formas, formações superficiais e vegetação próprias. Estas unidades têm na vegetação o seu principal elemento de caracterização fisionômica e podem ser enquadradas na categoria dos geossistemas (BERTRAND 1968). Variações de forma e grau de dissecação do relevo - determinadas pelo comportamento diferencial do substrato frente ao intemperismo, à pedogênese e à morfodinâmica - constituem a base de estruturação dos geossistemas dos altos campos e serrano, reconhecidos no planalto por MODENESI (1988a), como unidades de paisagem fisionomicamente heterogêneas, nas quais se acentuam o complexo geográfico e a dinâmica de conjunto. 
O geossistema dos altos campos (Figuras 2 e 4) caracteriza-se nas porções mais elevadas da borda sudeste do planalto, nos campos do Jordão e de São Francisco, e, para o interior, nos campos do Serrano. Essas áreas de campo ocorrem circunscritas por uma série de corredeiras ou cachoeiras e relativamente protegidas da dissecação fluvial mais enérgica. O relevo é caracterizado por contraste nítido entre as formas arredondadas do topo dos morros e lombas (na terminologia local, vertentes convexas recobertas por campo) e os setores dissecados das vertentes (vertentes retilíneas, setor retilíneo inferior das vertentes convexas, e anfiteatros de erosão). O mosaico de distribuição da vegetação é típico, ajustado à variação das formas e das condições ambientais; campos revestem topos de morro e lombas, matas ocupam as áreas mais dissecadas das vertentes e os vales (Figura 2); observa-se uma relação constante entre dissecação do relevo e presença de mata.

Nas áreas profundamente dissecadas pela drenagem subseqüente (ribeirões dos Marmelos, do Jacu e Coxim), a jusante dos altos campos, desenvolve-se o geossistema serrano (Figura 4), cujo modelado contrasta com o dos campos. Interflúvios estreitos, em cristas freqüentemente orientadas segundo as direções estruturais predominantes, vertentes retilíneas, abruptas, e amplitudes de até $700 \mathrm{~m}$ são característicos, mas a diferença mais marcante está no mosaico da vegetação: o campo desaparece do topo dos interflúvios e a mata tende a ocupar todos os níveis das vertentes.

\section{COMPARTIMENTAÇÃO \\ GEOMORFOLÓGICA DO VALE DO CAPIVARI}

A compartimentação geomorfológica geral dos altos campos do planalto, identificada e descrita anteriormente (MODENESI 1988a) entre o vale do Capivari e o Mirante do Itapeva, é também válida para a área de estudo, uma vez que esta se insere na sua porção mais típica. Os compartimentos geomorfológicos definidos não são apenas unidades morfológicas, estáticas, mas compartimentos dotados de dinâmica própria, relacionada a variações do substrato e/ou dos processos atuantes (MODENESI 1988a). Um mosaico de distribuição da

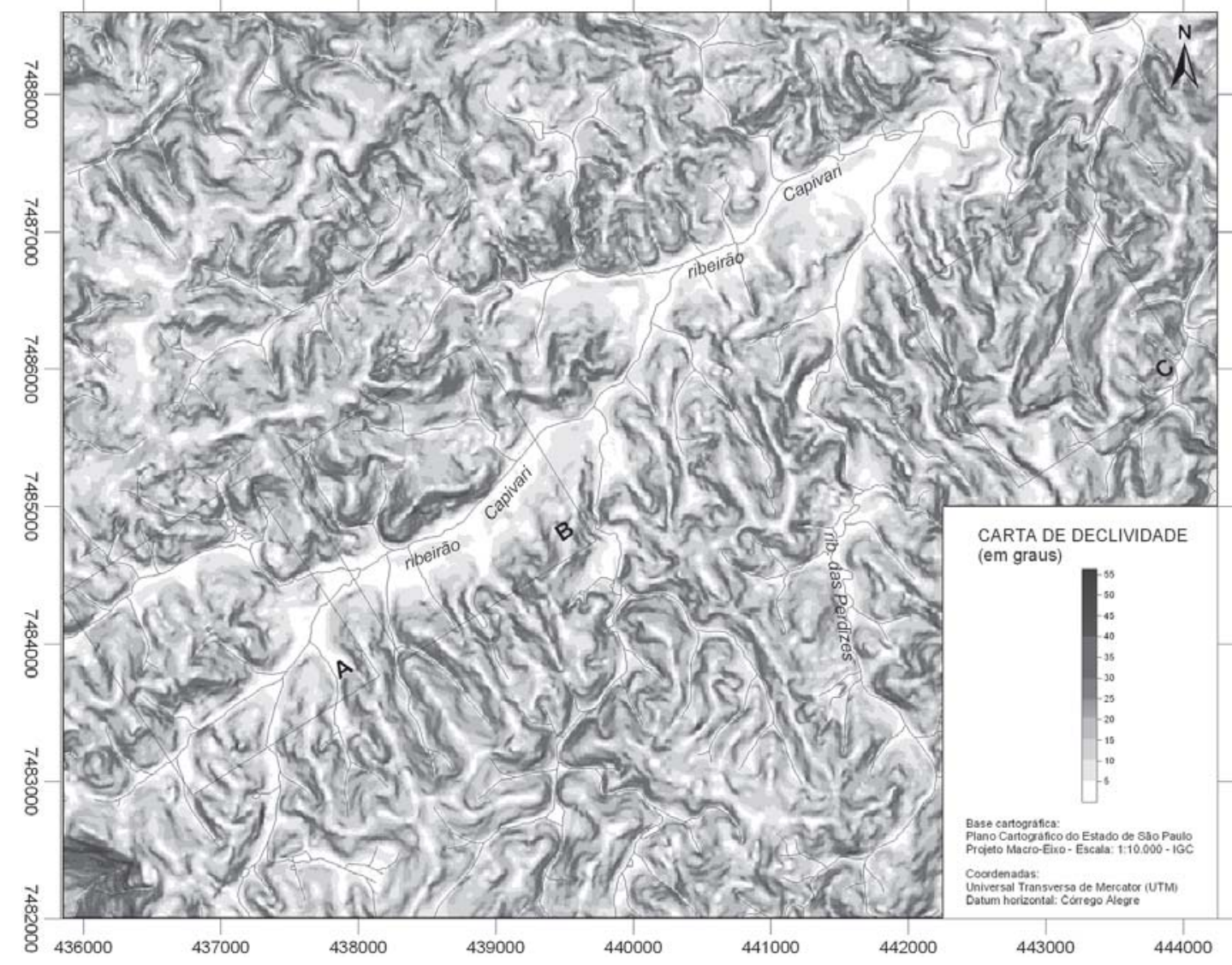

FIGURA 3 - Carta de declividade da bacia do ribeirão Capivari. Áreas de amostragem (A, B, C). 
vegetação fortemente relacionado à variação das condições ambientais acentua a diferença fisionômica entre os compartimentos. Estes constituem unidades fisionômicas e funcionais homogêneas e bem diferenciadas entre si, que integram os vários elementos da paisagem, e são, por este motivo, ideais para fins de aplicação em planejamento ou gerenciamento ambiental.

Pequenos ajustes foram feitos na classificação original para adaptá-la aos objetivos do projeto. Cinco compartimentos podem ser diferenciados no vale do Capivari: (1) áreas de topo, (2) lombas propriamente ditas, (3) vertentes retilíneas, (4) anfiteatros de erosão, (5) depressões turfosas e (6) planícies alveolares - incluindo várzeas, terraços e rampas de colúvio. Cada uma dessas unidades é caracterizada por combinações específicas de topografia e formas, substrato, processos atuantes e cobertura vegetal.

A compartimentação geomorfológica das três áreas de amostragem é apresentada nas figuras 5, 6, e 7 , nas quais estão registrados topografia e formas, declividade, foliação metamórfica e processos erosivos predominantes nas vertentes - erosão laminar fraca, moderada e intensa e movimentos de massa atuais. Declividade geral do vale do Capivari/ Sapucaí-Guaçu e litologia do planalto constam, respectivamente, das figuras 3 , 2 e 4 .

\section{1 Áreas de topo}

Neste compartimento estão incluidos os topos de morro e a parte superior das lombas, áreas com características morfológicas, condições hidrológicas e formações superficiais semelhantes, que podem ser reunidas numa só unidade geomorfológica. Os divisores dos principais formadores do Sapucaí-Guaçu ocorrem embutidos na superfície cimeira do planalto (nesta área, a 1900$1950 \mathrm{~m}$ ), subnivelados a altitudes que decrescem para norte e noroeste em três níveis topográficos, situados a 1800/1820m, 1710/1740m e 1640/1660m (MODENESI 1988a), os dois mais baixos bem representados na zona urbana de Campos do Jordão (Figura 8). O nível intermediário (1710/1740 m) (Figura 9) é mais extenso sobre gnaisses bandados

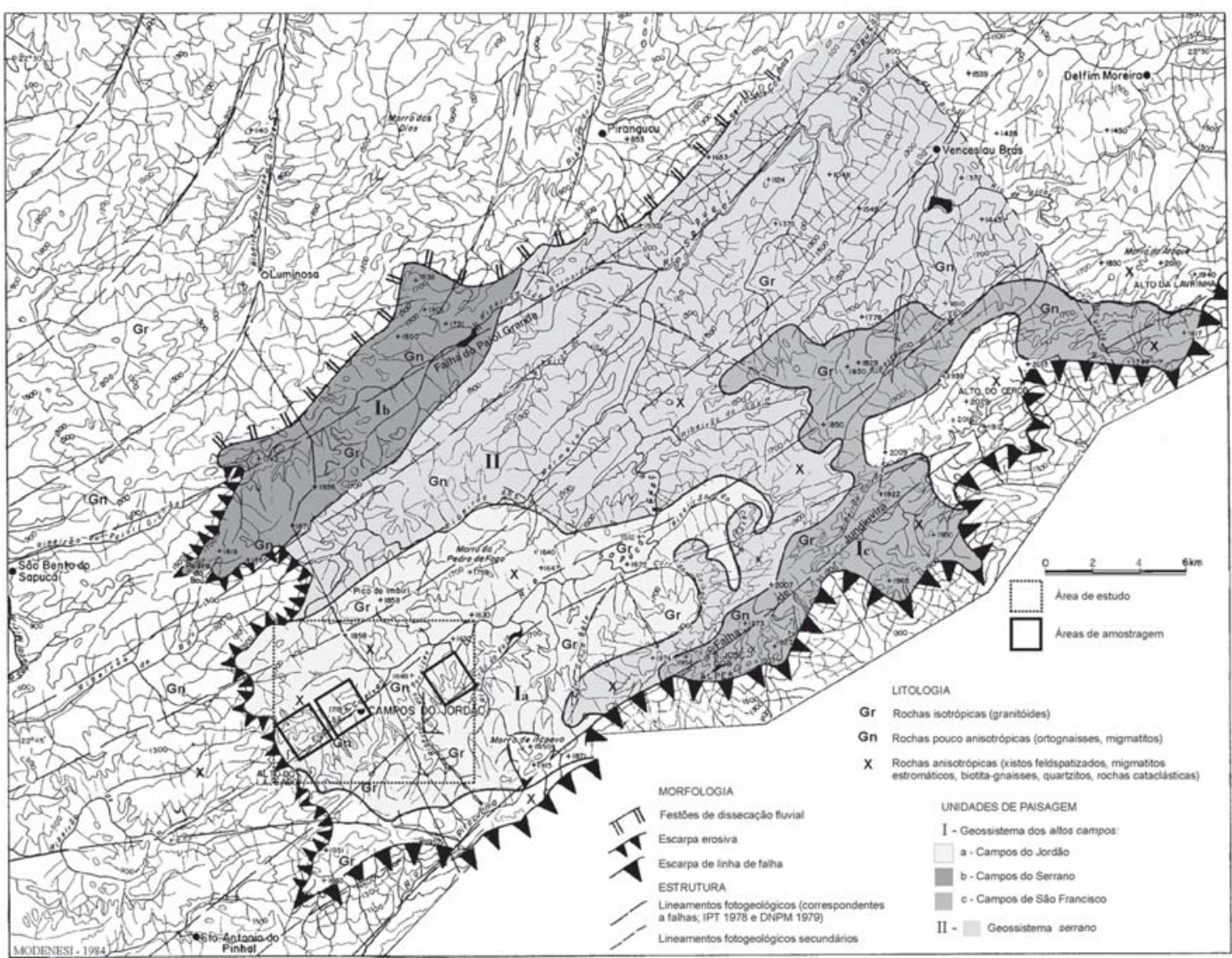

FIGURA 4 - Os geossistemas dos altos campos e serrano no planalto de Campos do Jordão (Adaptado de MODENESI 1988a). 


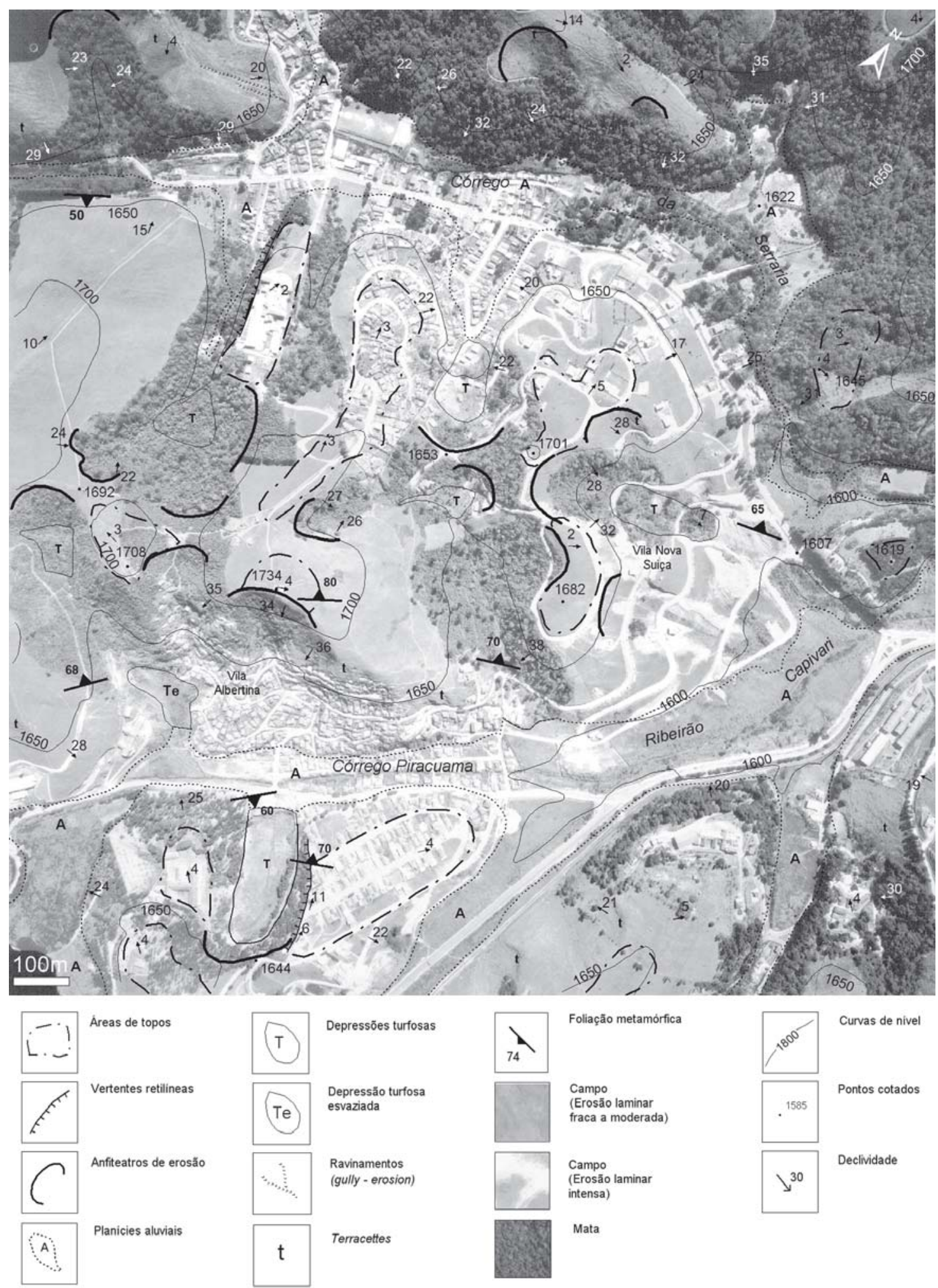

FIGURA 5 - Esboço geomorfológico da área de amostragem A. 

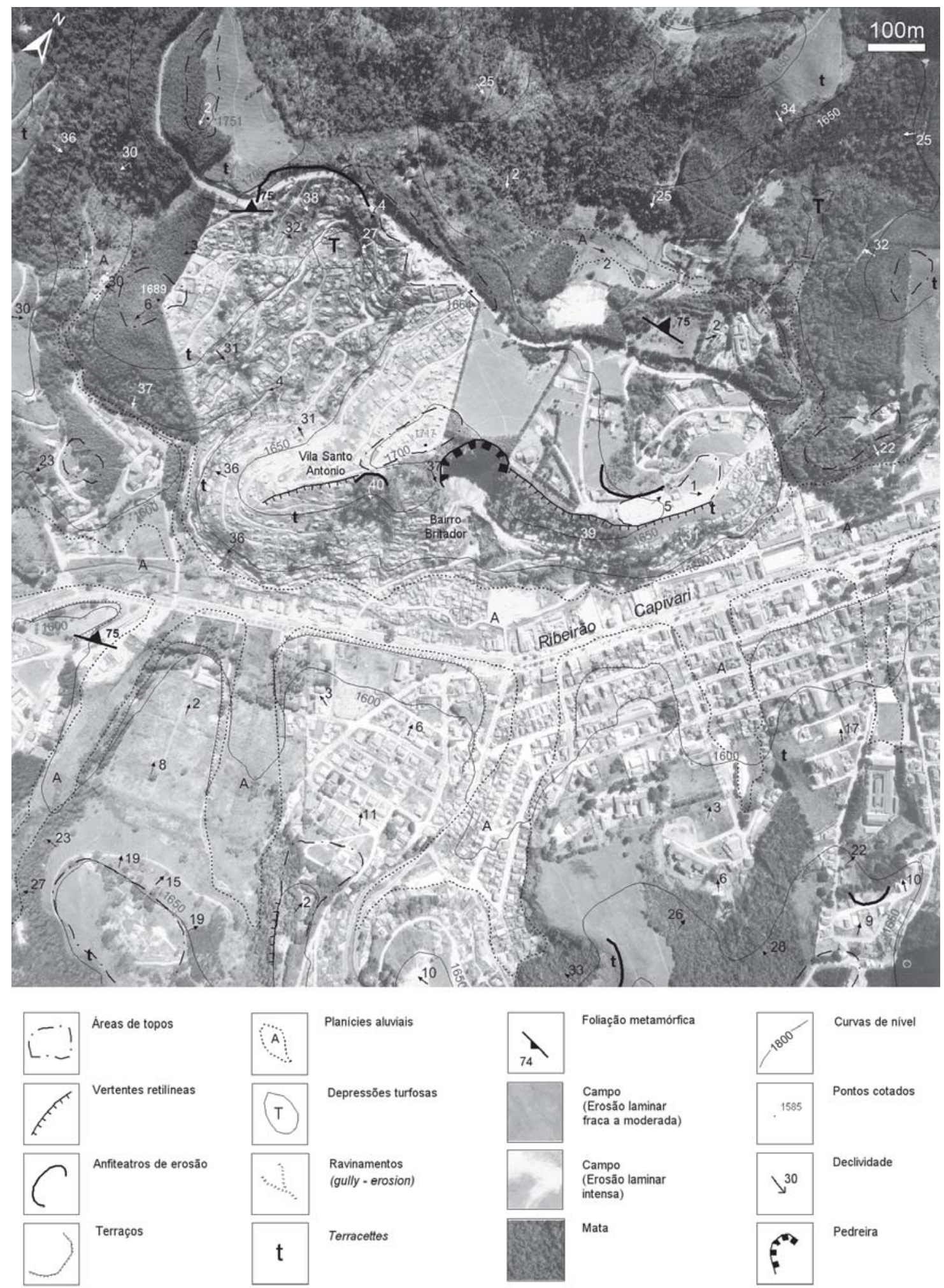

Curvas de nivel
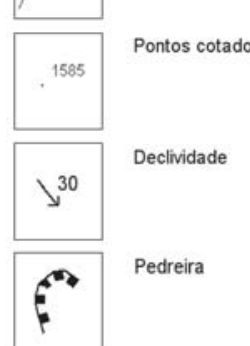

Pedreira

FIGURA 6 - Esboço geomorfológico da área de amostragem B. 

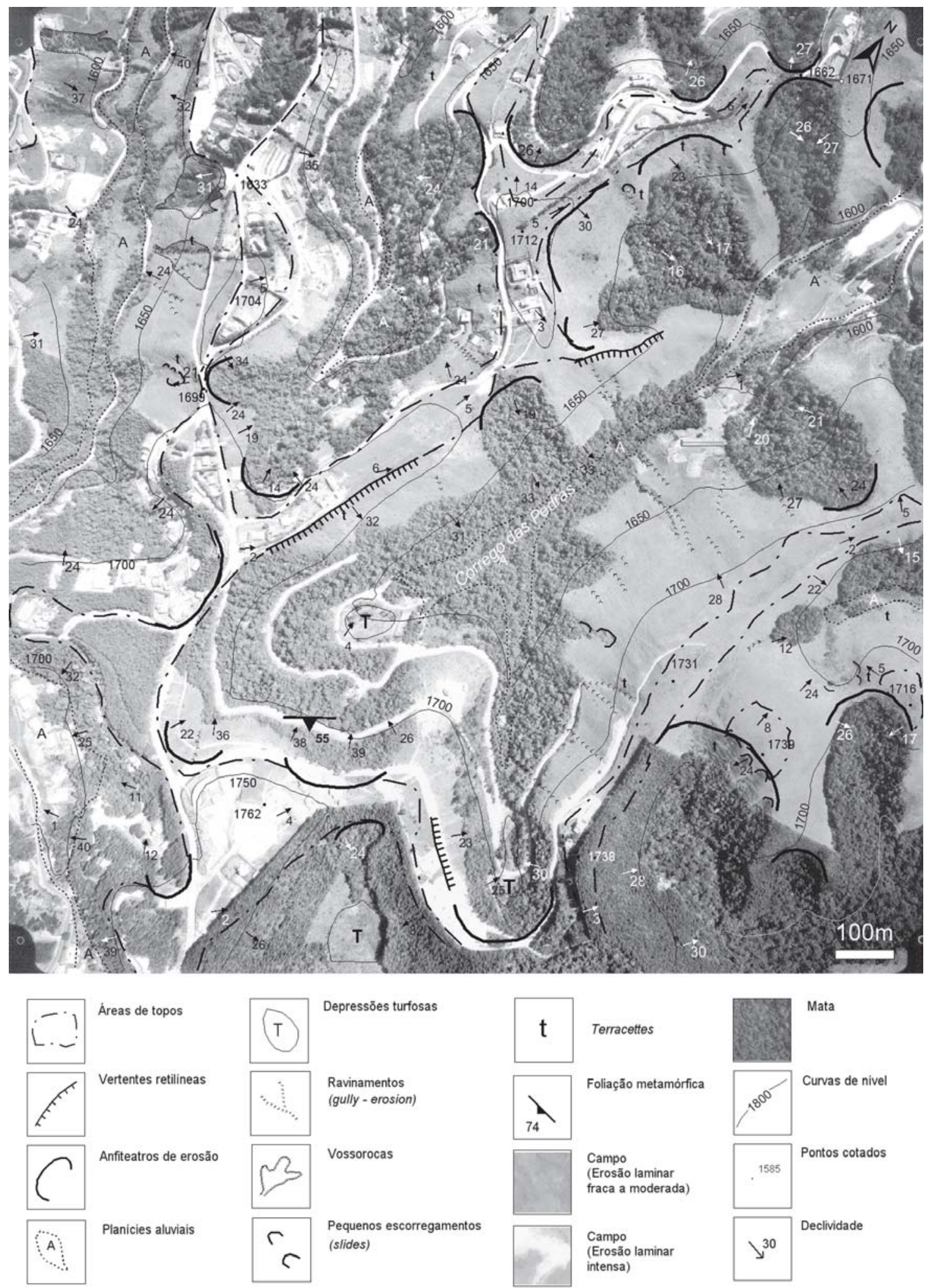

FIGURA 7 - Esboço geomorfológico da área de amostragem C 
da margem direita do Capivari; na margem esquerda, sobre quartzitos, tem sua área reduzida e acentuados os desníveis que o separam das colinas mais baixas, ou da planície aluvial. As colinas do nível inferior (Figura 8) ocorrem ao longo dos ribeirões Capivari e das Perdizes, sobre gnaisses bandados.

O topo dos morros tem seção convexa, mais larga e arredondada sobre gnaisses e granitos, mais estreita sobre xistos e quartzitos. Declividades de 2 a $5^{\circ}$ e, excepcionalmente, $8^{\circ}$ caracterizam o setor superior das lombas. Nestas áreas relativamente secas e revestidas por vegetação de campo, o lençol freático encontra-se, com freqüência, a mais de $30 \mathrm{~m}$ de profundidade. Materiais de cobertura pouco espessos (10 a 30cm e excepcionalmente $50 \mathrm{~cm}$ ) e solos ácidos, com horizonte A friável - litossolos ou solos com B incipiente (OLIVEIRA et al. 1975) - são comuns. Solos de textura argilosa predominam nos morros de altitude inferior a 1800/20 m; perfis sobre granito apresentam cascalho de quartzo e maior porcentagem de areia grossa. O contato com a rocha alterada é quase sempre marcado por linha de seixos; a rocha alterada é coesa e dura, com as estruturas bem preservadas. Os materiais de topo são os mais intemperizados (MODENESI 1980, 1983), com a fração mineral dos solos e a rocha alterada constituidos quase exclusivamente por quartzo, gibbsita e caulinita, e totais caolinita + gibbsita superiores a $50 \%$. Restos de lateritas in situ podem aflorar na borda dos topos, na primeira ruptura de declive dos morros de altitude superior a $1800 \mathrm{~m}$. Topos são áreas de vegetação de campo (Figura 7): campos limpos, constituídos por vegetação herbácea e graminosa, e campos sujos, com ervas, subarbustos, arbustos e arvoretas isoladas; acima de $1800 \mathrm{~m}$ ocorrem campos de altitude semelhantes aos das outras cimeiras do Brasil de sudeste (SIEBERT et al. 1975).

Escoamento superficial de tipo anastomosado (MORGAN 1986, MOYERSONS 1989, MODENESI \& JORDÃO 1992) e erosão laminar/sheet erosion moderada são característicos dos campos das áreas de topo (Figura 10).

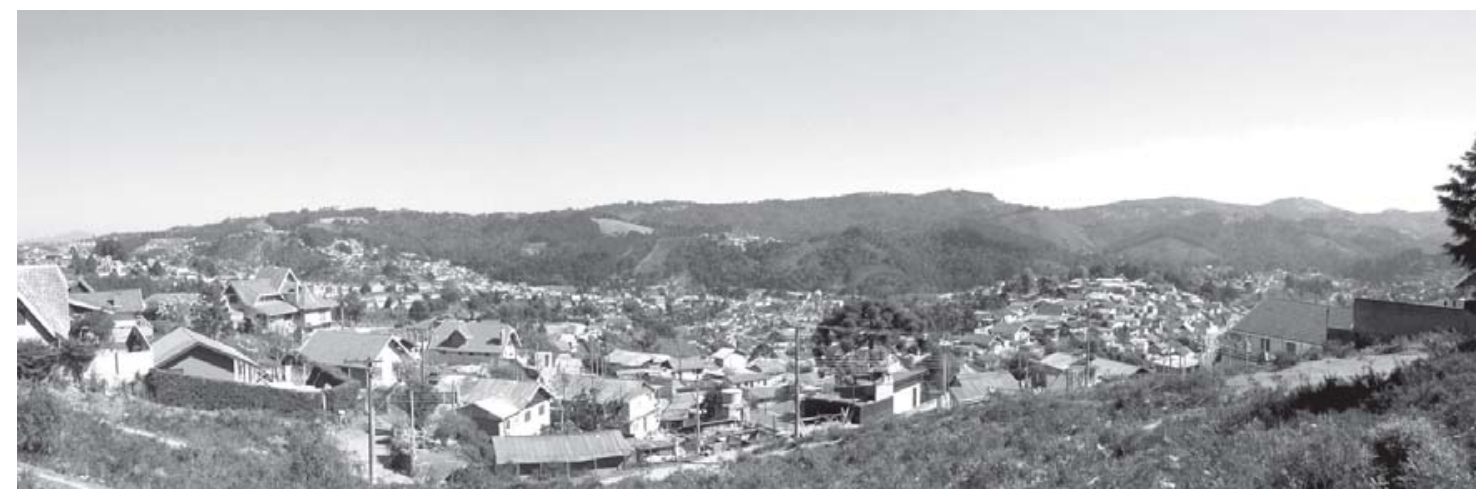

FIGURA 8 - Os três níveis topográficos reconhecidos no vale do ribeirão Capivari a altitudes de 1800/20m, 1710/40m e 1640/60m. Note-se a total ocupação das colinas correspondentes ao nível inferior.

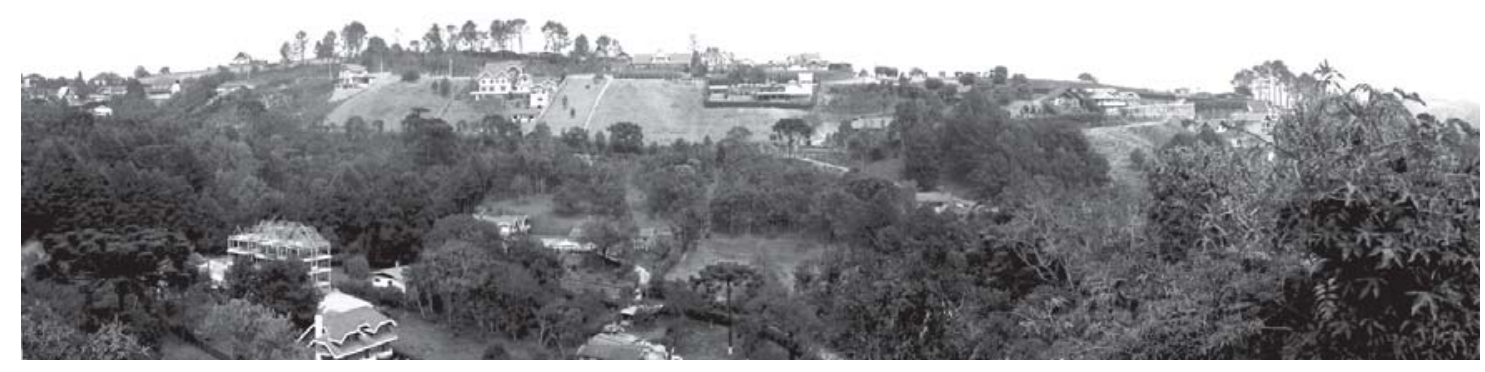

FIGURA 9 - Morro do nível intermediário (1710/40m), no alto da Vila Inglesa. Exemplo da ocupação de áreas mais estáveis por residências de alto padrão, construídas em terrenos amplos nos topos de morro e lombas. 


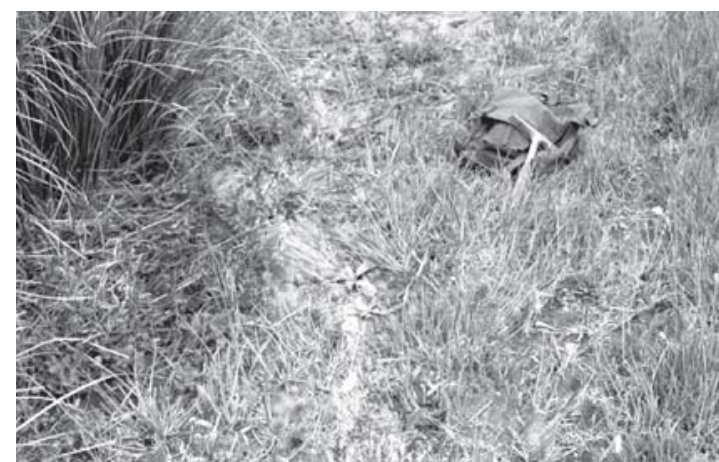

FIGURA 10 - Depósito de areia branca sobre cobertura de campo, evidência da ação do escoamento superficial anastomosado e erosão laminar intensa.

\subsection{Lombas propriamente ditas}

Pouco inclinadas no setor superior, as lombas (Figuras 11 e 12) podem apresentar, a partir do setor médio, perfis em rampa, mais íngremes (em torno de $20^{\circ}$ ) sobre substrato rochoso e menos inclinados $\left(12-15^{\circ}\right)$, ou formando patamares, nos locais de acumulação de colúvios (Figura 13). Seu setor terminal pode ser retilíneo ou, em planícies alveolares como a do ribeirão Capivari, ligeiramente côncavo (rampas de colúvio). Lombas são ambientes relativamente secos, caracterizados por dispersão do escoamento superficial e das águas de percolação e por menor profundidade do intemperismo; na sua parte convexa, o lençol freático encontra-se geralmente a mais de $20 \mathrm{~m}$ de profundidade.

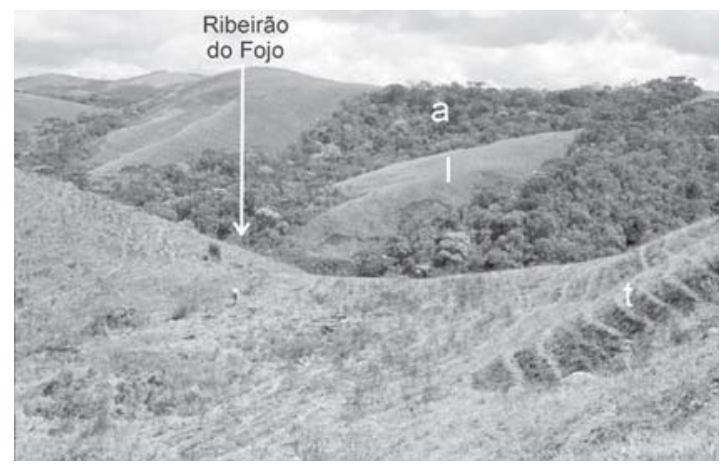

FIGURA 11 - Anfiteatros com mata (a) e lombas recobertas por campo (l) no vale do ribeirão do Fojo. Em primeiro plano, microterraceamento (terracetes, t) característico da morfologia das lombas (comum acima de $20^{\circ}$ ).
Os materiais de recobrimento das lombas são rasos, com características morfológicas e mineralógicas semelhantes às dos materiais dos topos. Colúvios mais espessos, com elementos rudáceos menores e em menor número e horizontes húmicos enterrados, podem ocorrer no terço inferior das lombas, caso de Vila Nova Suíça, ou em bolsões e patamares. O horizonte A dos solos das lombas é geralmente menos argiloso, com maior concentração da fração areia em relação à rocha subjacente. $\mathrm{O}$ grau de alteração dos solos e da rocha alterada é um pouco inferior ao observado nos topos; nos depósitos, depende da alteração dos materiais de montante. Campos semelhantes aos do topo dos morros ocorrem nas lombas; nas vertentes mais secas predominam campos sujos.

Lombas com declividade em torno de $10^{\circ}$ podem apresentar erosão em filetes/rills (MODENESI \& JORDÃO 1992) e, acima de $20^{\circ}$, terracettes ( Figuras 5, 6, 7 e 11) e ravinamentos/gullies (Figuras 5 e

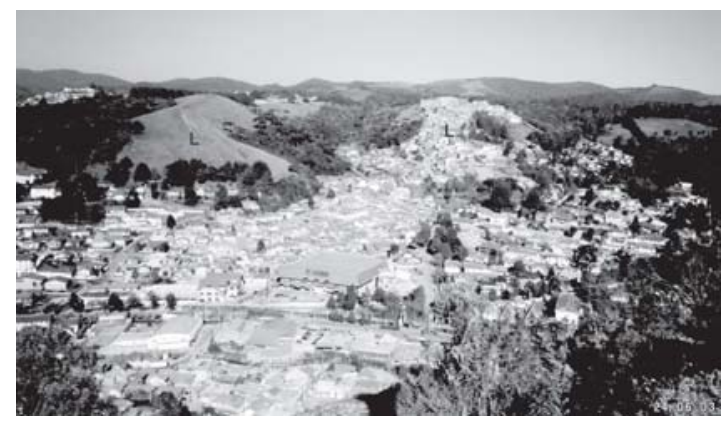

FIGURA 12 - Lombas (L) dos morros mais baixos do vale do Capivari, em Abernéssia. Note-se a densa ocupação dos compartimentos de menor declividade, inclusive da várzea.

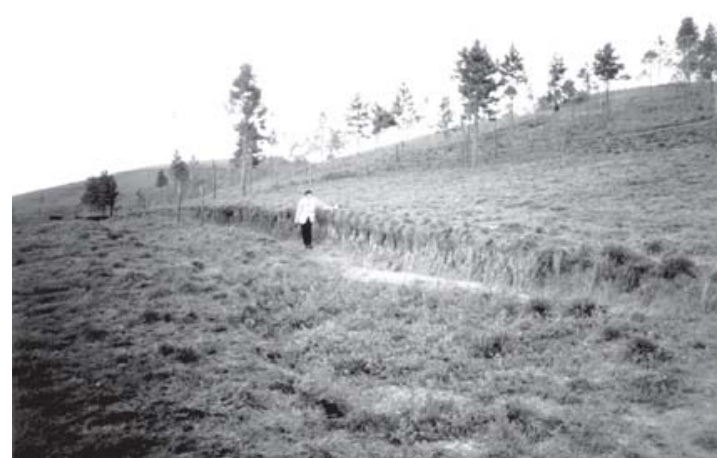

FIGURA 13 - Patamar formado pela deposição de colúvios no setor médio de lomba; nestes locais são também freqüentes bolsões de solo com horizontes-A enterrados. 
7). Ravinamentos também podem ocorrer na passagem do setor convexo para o retilíneo inferior, onde aumento e mudança de declividade favorecem a concentração do escoamento das águas pluviais de montante.

\subsection{Vertentes retilíneas}

O perfil das vertentes retilíneas (Figuras 6, 7 e 14) é geralmente caracterizado por convexidade superior pouco acentuada; vertentes totalmente retilíneas ocorrem apenas em vales muito encaixados. Setores basais côncavos são raros. Nas vertentes mais íngremes é típico o terraceamento em pequenos degraus (terracettes/ pieds de vache). Vertentes retilíneas são comuns sobre quartzitos, mas ocorrem também sobre outras rochas, em áreas de

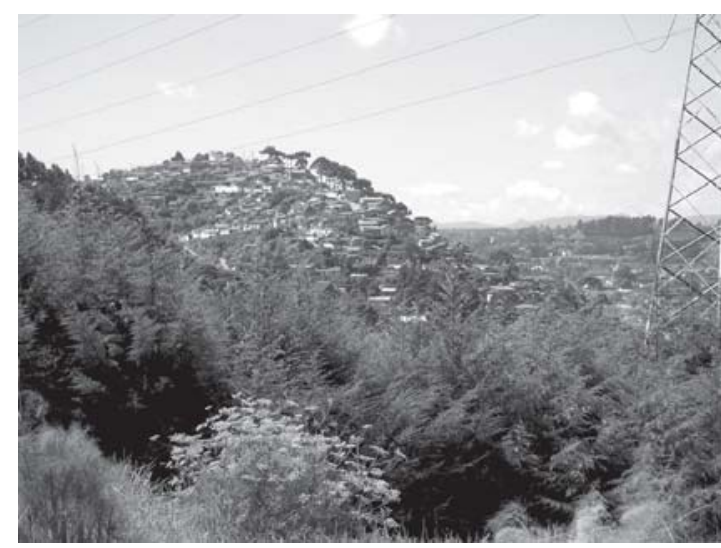

FIGURA 14 - Morro do nível intermediário (1718m) com vertentes retilíneas de declividade superior a $35^{\circ}$ ocupadas por residências de baixo padrão (Vila Santo Antônio).

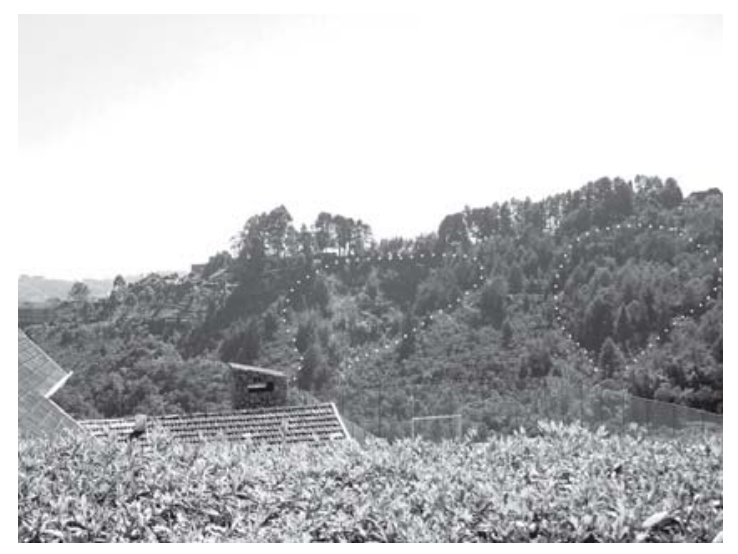

FIGURA 15 - Voçorocas desenvolvidas em vertente retilínea com declividade de $24 / 32^{\circ}$, sobre gnaisses bandados (Nova Capivari). Apesar da tentativa de contenção com plantio de Pinus, em alguns pontos há reincidência da ação erosiva de movimentos de massa e ravinamentos. maior amplitude e dissecação do relevo, freqüentemente associadas a alinhamentos estruturais. Sobre rochas gnáissicas e xistosas, perfis retilíneos caracterizam as vertentes contrárias ao mergulho das foliações, em geral, elevado.

O setor superior convexo das vertentes retilíneas, relativamente estável, possui formações superficiais rasas e muito intemperizadas, semelhantes àquelas do setor superior das lombas e topo dos morros. Na vertente retilínea propriamente dita, ações erosivas fizeram aflorar as zonas mais profundas dos perfis de alteração e mesmo a rocha sã; a instabilidade destas áreas essencialmente dinâmicas é comprovada pela ocorrência de solos rasos menos intemperizados. Os solos das vertentes retilíneas são os menos evoluídos do planalto, com valores mínimos da soma caulinita + gibbsita (MODENESI 1980); o grau de intemperismo da rocha alterada é, também, nitidamente inferior. Alguns depósitos e solos mais espessos podem existir nas vertentes médias, em pequenos patamares com declividade de até $12^{\circ}$, ou nas rampas de colúvio dos setores basais. Sob mata são comuns latossolos e solos podzólicolatossólico-húmicos (MODENESI et al. 1982), semelhantes aos das vertentes íngremes dos anfiteatros. A mata geralmente ocupa o setor inferior das vertentes (Figura 7) e somente nos perfis inteiramente retilíneos pode atingir sua porção superior; a maior parte das vertentes retilíneas é recoberta por campo.

A ocorrência generalizada de solos rasos e menos intemperizados evidencia a desnudação mais rápida destas vertentes, áreas essencialmente dinâmicas. Sua instabilidade é comprovada pela presença de alguns depósitos, no setor basal e em pequenos bolsões das vertentes, e de horizontes humíferos enterrados. Ravinamentos, voçorocas (Figuras 7, 15) e escorregamentos podem ocorrer nas vertentes retilíneas (Figura 7). Nas encostas sombrias, voltadas para sul e sudeste, o impacto direto das chuvas frontais aumenta a vulnerabilidade a processos erosivos.

\subsection{Anfiteatros de erosão}

Anfiteatros de erosão (Figuras 5, 6, 7 e 16) são rentrâncias originadas por importantes e profundos movimentos de massa (MODENESI 1988a, $1988 \mathrm{~b})$ que dissecaram de alto a baixo as vertentes convexas dos altos campos; não se restringem apenas às cabeceiras de drenagem mas ocorrem lateralmente ao longo dos vales. Nos anfiteatros de erosão, topografia e forma favorecem a concentração 
do escoamento superficial e subsuperficial, caracterizando-os como ambientes úmidos, com intemperismo e solos relativamente mais profundos (MODENESI 1988a, 1988b). A vegetação característica destas áreas é a mata de Araucaria e Podocarpus densa e rica em epífetas e lianas.

Nas bacias dos ribeirões Capivari e das Perdizes o diâmetro dos anfiteatros varia de 80 a 230m; formas maiores podem resultar da coalescência de vários anfiteatros. Os anfiteatros ocorrem sempre suspensos em relação aos talvegues atuais, dos quais se separam por degraus rochosos ou rampas frontais (Figura 16B). Seu perfil longitudinal é caracterizado por pequena convexidade superior, abruptos com declividades de 23 a $35^{\circ}$ na parte lateral e até $45^{\circ}$ na parte posterior, e secção inferior côncava; rampas suavemente inclinadas $\left(2^{\circ}\right.$ a $\left.3^{\circ}\right)$ correspondem à superfície das bacias turfosas desenvolvidas na

A
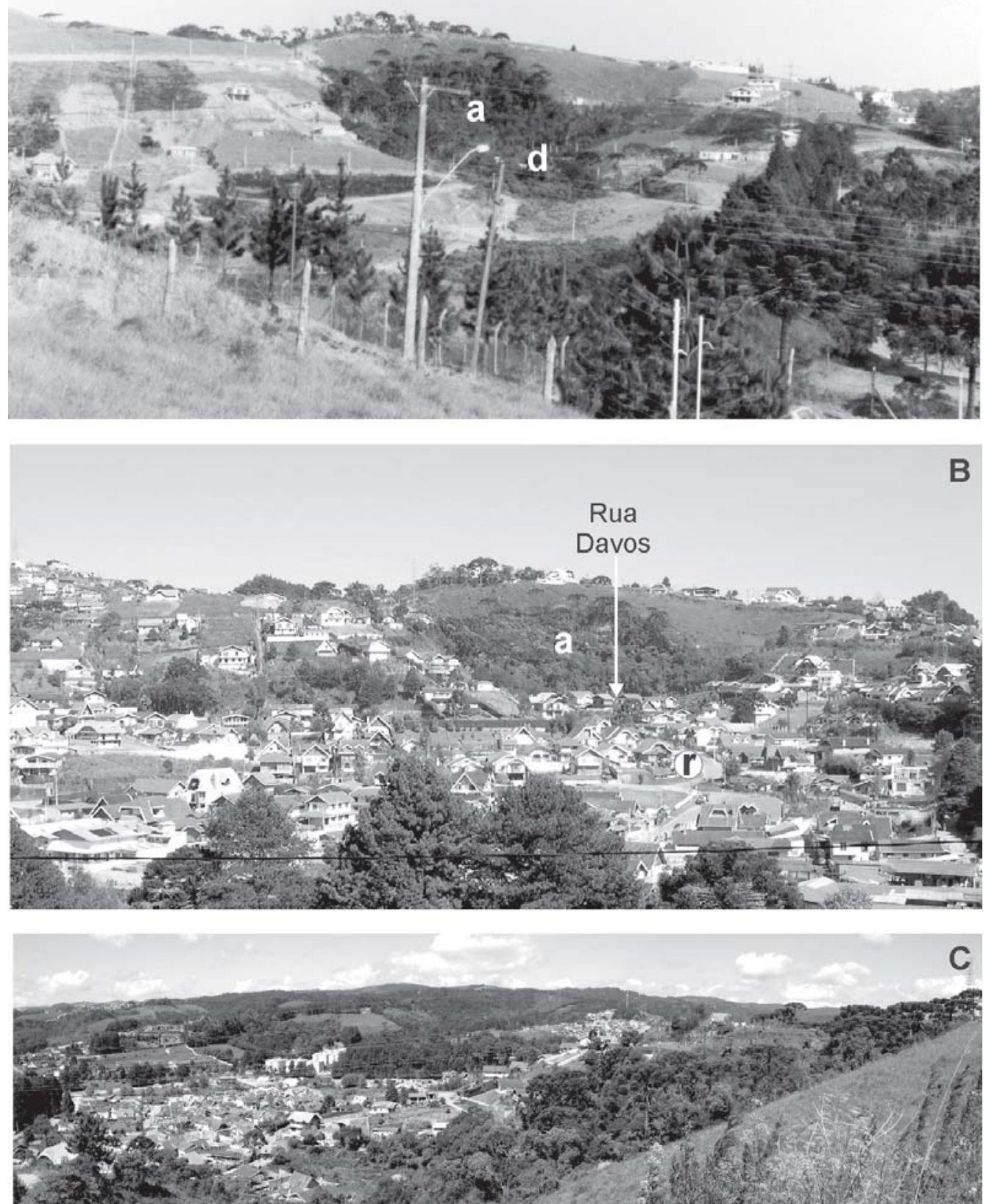

FIGURA 16 - Expansão urbana nas vertentes de morros do nível intermediário (1710/40m), em Vila Nova Suiça; 1983 (A) e 2005 (B). A única área preservada é o anfiteatro (a), que apresenta declividades de até $40^{\circ}$; note-se a ocupação, total, da rampa frontal (r) e, parcial, da depressão turfosa (d). (C) No mesmo local, vista lateral do anfiteatro e de sua rampa. 
sua base. O perfil transversal típico é em calha, com o fundo ligeiramente inclinado das bordas para o centro e para jusante, perfis em V são menos comuns. A amplitude topográfica varia de 30-40m a $100 \mathrm{~m}$, mas pode chegar a $150 \mathrm{~m}$ na margem direita do ribeirão das Perdizes. Sobre gnaisses e granitóides são amplos e semicirculares; o regolito relativamente homogêneo, argiloso e profundamente intemperizado favorece movimentos de massa profundos. Em quartzitos e rochas xistosas os anfiteatros são menos marcados e, às vezes, alongados. Formas menores ou nichos com morfologia típica de corridas de lama (cicatriz côncava e base levemente bosselada) ocorrem, por exemplo, no vale do ribeirão Piracuama, em Vila Nova Suíça, pouco acima das várzeas atuais.

Áreas essencialmente dinâmicas da paisagem, os anfiteatros são há longo tempo o sítio preferencial da atividade morfogenética nas encostas, onde formas e depósitos evidenciam recorrência de movimentos de massa, escorregamentos e corridas de lama (MODENESI 1988a, 1988b); rocha sã ou pouco alterada pode aflorar nas suas bordas. Por isso a superposição de colúvios com horizontes humíferos enterrados é comum nas vertentes dos anfiteatros.

Depósitos espessos, grossos, heterométricos e sem estruturas - com seixos, blocos e matacões do substrato dispersos em matriz síltico-arenosa, argilosíltico-arenosa ou areno-síltico-argilosa -, preservados em patamares suspensos no interior dos anfiteatros, acima do limite das matas, testemunham a ação de movimentos de massa na abertura dessas reentrâncias. Tais depósitos podem estar recobertos por colúvios avermelhados menos grossos e por materiais amarelados de textura mais fina e homogênea, sobre os quais se desenvolvem solos de Campos do Jordão (COMISSÃO DE SOLOS 1960). Ações secundárias e locais do escoamento superficial são evidenciadas pela deposição de camadas arenosas estratificadas e acumulação residual de blocos e matacões.

\subsection{Depressões turfosas}

Depressões mal drenadas (Figuras 5, 6, 7 e 17) com área geralmente inferior a 2ha e superfície suavemente inclinada $\left(2-3^{\circ}\right)$ ocorrem na base dos anfiteatros, suspensas acima dos talvegues atuais . Escavadas na rocha subjacente estas pequenas bacias são colmatadas por seqüências turfosas de estrutura fibrosa, com até $3 \mathrm{~m}$ de espessura, freqüentemente interrompidas por lentes ou camadas esporádicas de areia (Figura 18) e, às vezes, tamponadas por materi- ais provenientes das encostas; as camadas escuras e humificadas apresentam grande variação textural e baixo teor de argila. Sobre estes materiais desenvolvem-se solos orgânicos ácidos com teores de matéria orgânica entre 13 e 55\%, insuficientes para definir turfeiras verdadeiras; com importante fração mineral,

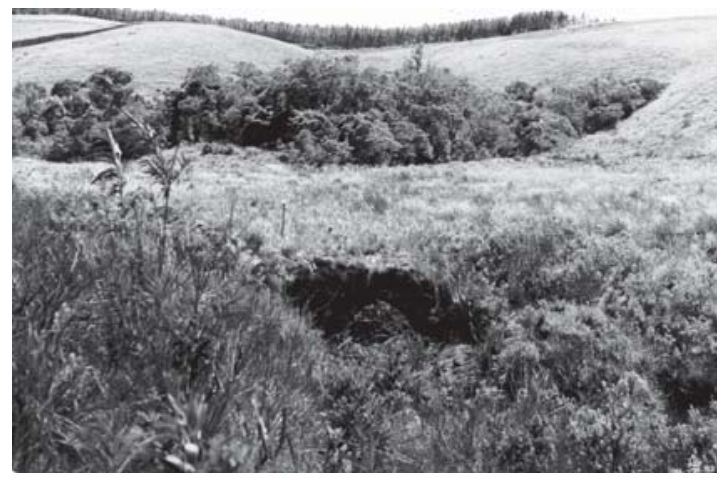

FIGURA 17 - Depósito turfoso na base de anfiteatro relacionado ao nível intermediário (1710/1740m) e suspenso acima do talvegue do ribeirão das Perdizes. Espessura aproximada de 3m (Jardim Primavera).

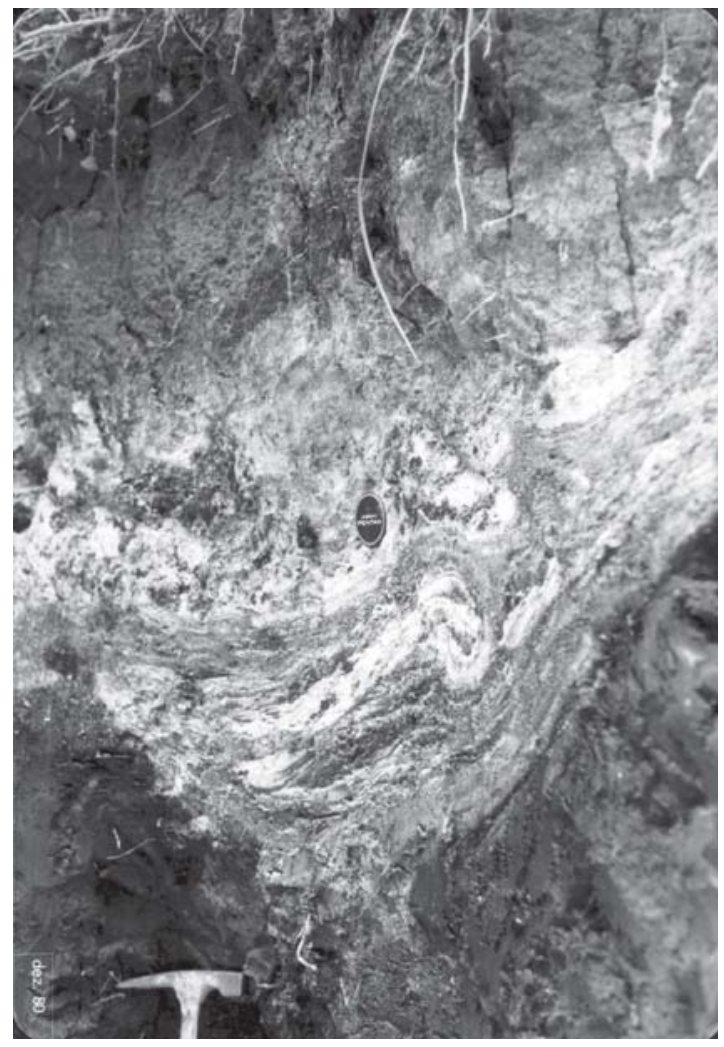

FIGURA 18 - Bolsão arenoso intercalado nos sedimentos turfosos que colmatam depressão de base de anfiteatro em Vila Nova Suiça. Estruturas formadas por sobrecarga diferencial, pela deposição de areia proveniente das encostas sobre a lama turfosa, testemunham a instabilidade destes sítios. 
constituem turfeiras tropicais (MODENESI 1988a). A deposição de materiais grossos no interior (Figura 18) ou na superfície das seqüências turfosas (lobos de fluxos de detritos com as formas bem preservadas) evidencia recorrência de ações erosivas no interior dos anfiteatros (MODENESI 1988a).

A vegetação atual dessas turfeiras inclui plantas herbáceas e pequenos arbustos adaptados às variações locais das condições hidrológicas. Na estação chuvosa, o lençol freático geralmente aflora na maior parte do depósito. O acúmulo de águas do escoamento superficial e subsuperficial e a dificuldade de drenagem característica destes sítios são fatores determinantes de instabilidade e da ocorrência de escorregamentos e corridas de lama.

\subsection{Planícies alveolares}

Pequenas planícies alveolares (Figuras 5, 6 e 7) desenvolvem-se a montante de soleiras rochosas, intercaladas com segmentos encaixados dos principais cursos d’água do planalto. A área reduzida e os coluvinamentos múltiplos ocorridos nas suas bordas (rampas de colúvio), no limite com as vertentes, contribuiram para mascarar os baixos terraços e várzeas, formas e depósitos típicos destes compartimentos. Mata de Araucaria e Podocarpus ocupa os vales, com adensamento da população de Podocarpus nas várzeas mais úmidas.

As raras, estreitas e pouco desenvolvidas planícies de inundação são constituídas por sedimentos finos, sem materiais turfosos como os da base dos anfiteatros. Setores de várzea ao longo do Capivari (Figuras 5 e 6) têm largura geralmente inferior a 100m, alargando-se um pouco (até 200m) apenas na confluência dos afluentes principais (Figuras 5, 19). Depósitos grossos de baixos terraços com cascalho $\left(T c_{1}\right.$ e $\left.T c_{2}\right)$ ocorrem com a espessura reduzida, retrabalhados e recobertos por colúvios, neste caso apresentando declividades de até 5-6 ${ }^{\circ}$ (Figura 6); constituem, quase sempre, seqüências complexas, com características aluviocoluviais (MODENESI 1988a) \% caso das rampas do sopé do Morro do Elefante, em Capivari.

Na borda das planícies aluviais e depressões turfosas, coluvionamentos múltiplos retrabalharam os materiais de vertente formando rampas de colúvio, que modificam o perfil do setor inferior das encostas. Rampas com declividade de $6-8^{\circ}$ e até $10^{\circ}$ desenvolvem-se nos vales mais amplos, muitas vezes incorporando topograficamente os baixos terraços à vertente; predominam texturas areno-argilosas ou argilo-arenosas, teores de silte entre 10 e $27 \%$, grânulos e seixos esparsos. Seqüências de até 3m de espessura ocorrem na margem direita do córrego Piracuama, afluente do Capivari, com camadas coluviais superpostas e freqüente intercalação de horizontes húmicos escuros.

\section{A EXPANSÃO URBANA E SUAS RELAÇÕES COM A COMPARTIMENTAÇÃO GEOMORFOLÓGICA}

O ribeirão Capivari constituti o eixo da ocupação e desenvolvimento urbano do maior dos alvéolos abertos no relevo do planalto de Campos do Jordão. A expansão urbana se fez a partir de três núcleos estabelecidos ao longo do vale, Abernéssia, Jaguaribe e Capivari (Figura 2). Inicialmente foram ocupadas as áreas de topografia mais favorável, terraços, rampas, lombas de menor declividade e topo das colinas mais baixas, respeitando as limitações do terreno e preservando o mosaico da vegetação dos altos campos. Entretanto, o rápido crescimento urbano observado nas últimas décadas, principalmente dos bairros residenciais médios e pobres, levou à ocupação de sítios instáveis das vertentes e

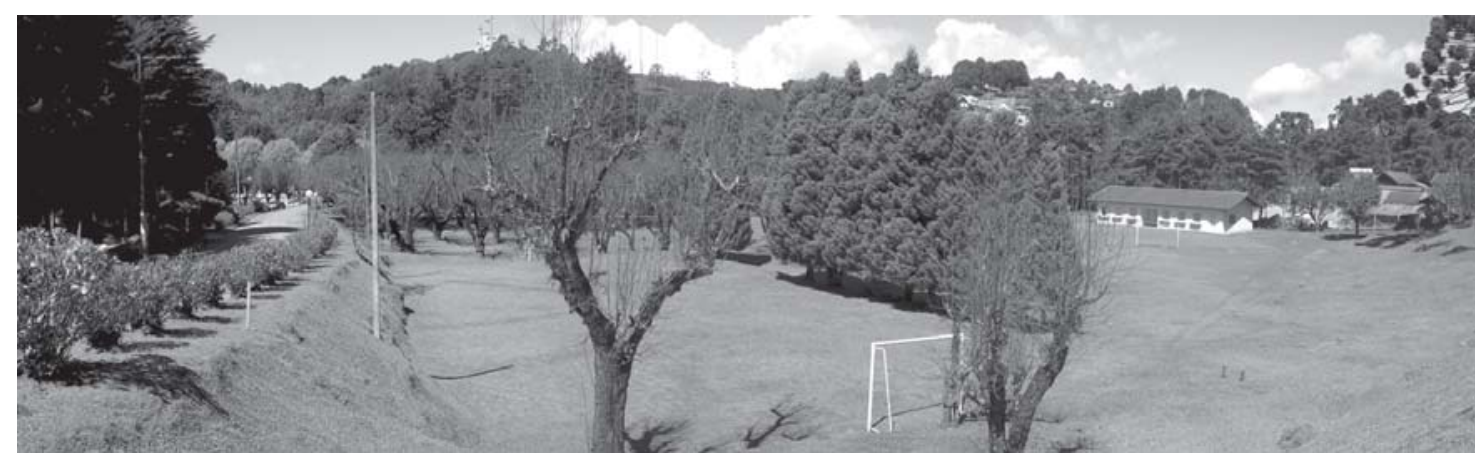

FIGURA 19 - Um dos poucos setores preservados da várzea do ribeirão Capivari, próximo à confluência com o ribeirão Piracuama, na entrada de Campos do Jordão. 
anfiteatros, descaracterizando o mosaico original da vegetação e criando graves problemas de degradação ambiental.

O mapeamento de três momentos da evolução urbana (Figura 20) permite analisar o crescimento físico da área de adensamento entre 1973 e 2000. Este período é importante por permitir registrar a expansão ocorrida nas décadas de 70 e 80 , justamente quando se verificou o ápice do desenvolvimento imobiliário e expansão do município, com multiplicação dos loteamentos (década de 70) e edificações (década de 80). É interessante notar que a expansão de Campos do Jordão se fez sentir antes da instituição de seu território como Área de Proteção Ambiental (APA), em 1983, portanto quando meio ambiente e recursos naturais ainda não eram considerados fatores importantes no planejamento urbano (SILVA 2002). Este fato foi agravado pela legislação municipal que, a partir de 1991, passou a considerar como urbana praticamente $80 \%$ da área do município, contribuindo para aumentar os problemas relacionados ao parcelamento de terrenos, à ocupação de áreas instáveis e, de modo geral, à degradação ambiental.

Considerando a área de maior adensamento de construções e excluindo os loteamentos pouco ocupados, em 1972 a mancha urbana correspondia a $3,7 \mathrm{~km}^{2}$, em 1983, a $6,7 \mathrm{~km}^{2}$, e em 2000, a 22,6km². Até 1973, as construções concentram-se ao sul do ribeirão Capivari, ocupando os sítios mais favoráveis, rampas de colúvio de menor declividade, baixos terraços e topo das colinas mais baixas. Na década seguinte inicia-se a ocupação das áreas instáveis; as vertentes íngremes da margem esquerda do Capivari, voltadas para sudeste, começam a ser invadidas (Figura 21).

A imagem de satélite de 2000 registra o resultado deste processo de expansão urbana, com a ocupação desordenada de vertentes de declividade superior a $30^{\circ}$ (vertentes retilíneas e anfiteatros) e depressões turfosas. Nestas áreas, hoje densamente povoadas, os problemas de degradação ambiental foram agravados pela subdivisão dos lotes e pelo padrão baixo ou, secundariamente, médio das cons-

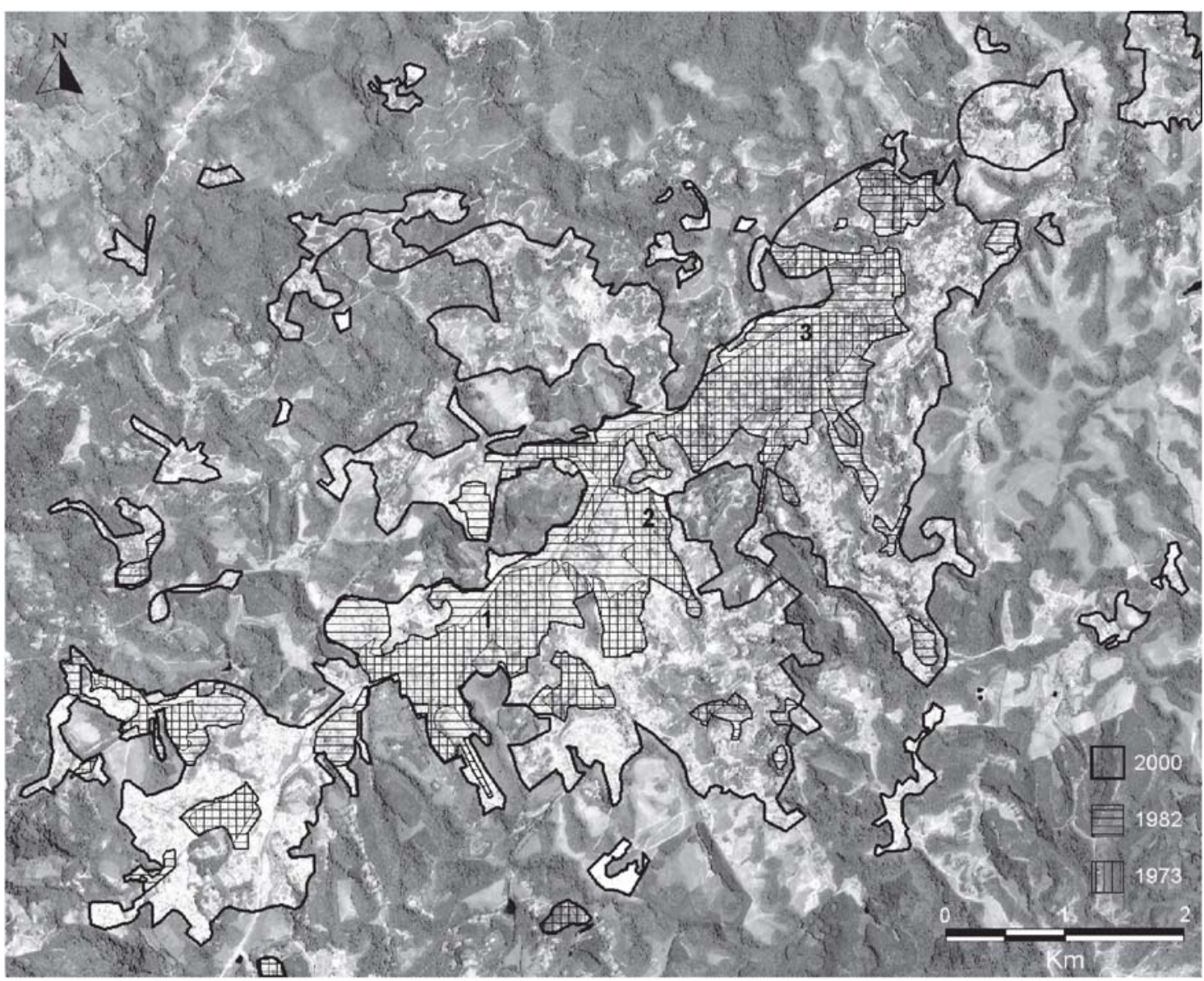

FIGURA 20 - Três momentos da expansão urbana no vale do Capivari. Observe-se a descaracterização do mosaico típico de distribução da vegetação de campo e mata (Imagem de satélite IKONOS, 2000). 

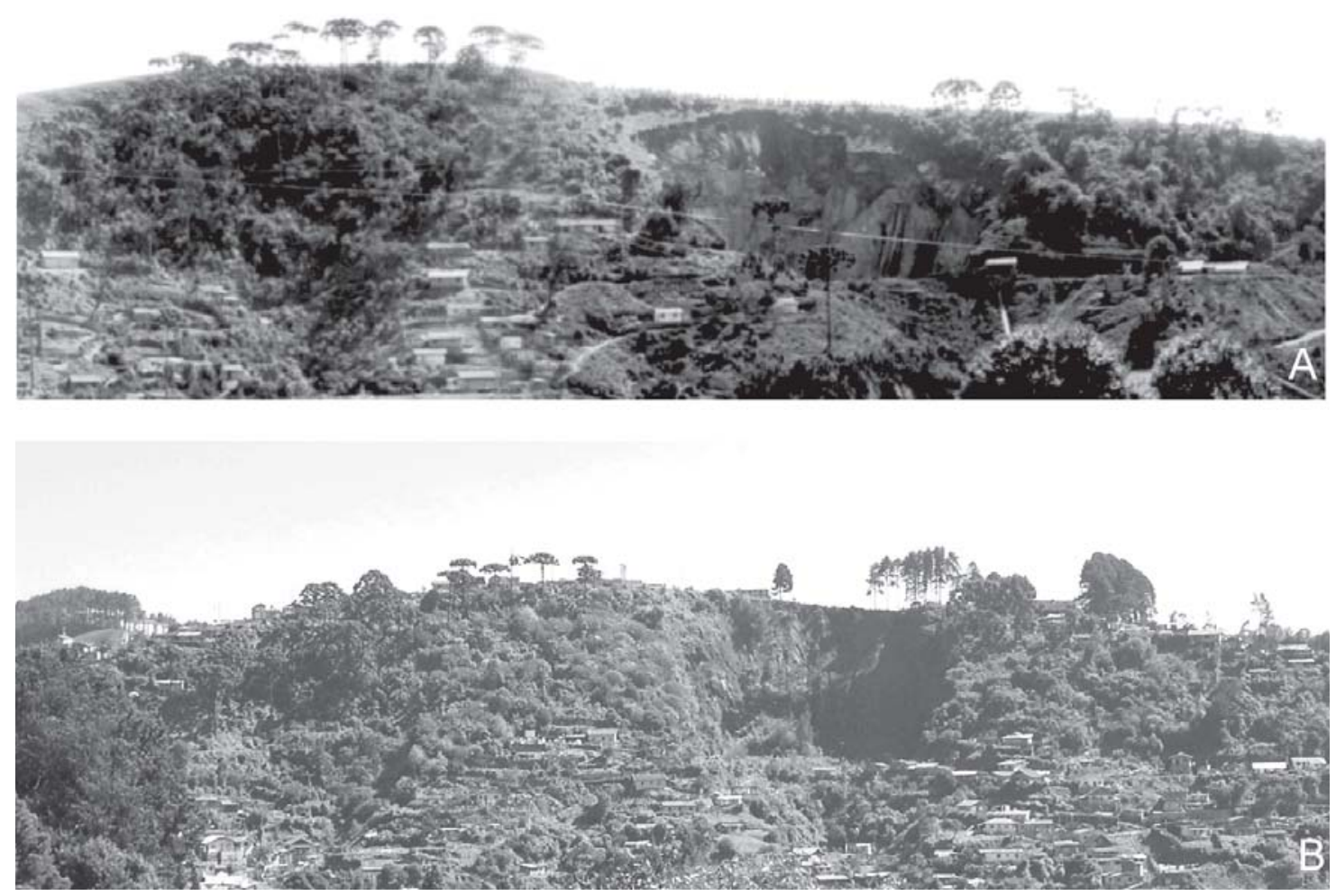

FIGURA 21 - Bairro Britador em 1983 (A) e 2005 (B). A comparação das fotos evidencia modificações introduzida na paisagem pela ocupação das encostas íngremes e sombrias da margem esquerda do Capivari. Na primeira, os anfiteatros que ladeiam a pedreira aparecem bem caracterizados, recobertos por mata com araucária. Na segunda foto observa-se o aumento da cava da pedreira por escorregamentos recentes e a modificação dos anfiteatros que a ladeiam; o recuo da mata é nítido no anfiteatro da esquerda; à direita desaparecem as araucárias e há total descaracterização do anfiteatro. Notase também que, apesar dos escorregamentos ocorridos na área, o número de construções não diminui.

truções, com adoção de técnicas geralmente inadequadas (Figuras 22 e 23). A várzea do Capivari foi sendo progressivamente ocupada por estabelecimentos comerciais (Figura 24) e habitações de diferentes tipos (Figura 25), inclusive, próximo a Jaguaribe, por construções precárias (Figura 26). Espaços livres são raros e permanecem por exemplo no setor de várzea relativamente amplo que existe próximo à confluência com o ribeirão Piracuama, na entrada de Campos do Jordão (Figura 19).

A expansão atingiu também o topo dos morros de nível intermediário (1710-1740 m) em Abernéssia e Jaguaribe, mas estas são áreas geomorfologicamente mais estáveis e onde ainda persistem propriedades maiores, o que atenua os problemas de degradação. Em Capivari (Figura 27), loteamentos de padrão mais elevado, geralmente em curvas de nível, com terrenos maiores, assim como a adoção de técnicas de construção mais apropriadas, caracterizam um padrão de urbanização com menor modificação do ambiente físi- co e certa preservação do mosaico de distribuição da vegetação de campo e mata.

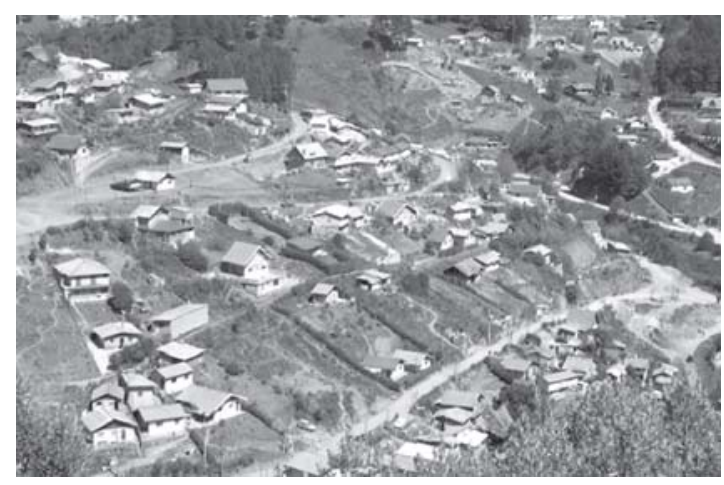

FIGURA 22 - Ocupação típica dos bairros de padrão médio e baixo, onde subdivisão dos lotes e adoção da técnica de corte e aterro agravam os problemas de estabilidade das lombas mais íngremes. 


\section{AS UNIDADES-DIAGNÓSTICO}

O conhecimento das características geomorfológicas dos sítios urbanos é básico na determinação do uso do solo e da susceptibilidade aos processos erosivos, permitindo reconhecer áreas de maior potencial de risco, que requerem atenção do poder público. Num relevo acentuado como o do planalto de Campos do Jordão, a identificação de setores mais ou menos favoráveis à ocupação torna-se essencial para o planejamento urbano.

Com o objetivo de atender à demanda por informações geomorfológicas que possam orientar a expansão urbana no planalto, o vale do Capivari foi dividido em unidades-diagnóstico, com diferentes aptidões para ocupação. Essas unidades tiveram como base compartimentos geomorfológicos caracterizados por formas, formações superficiais, processos dominantes e co- bertura vegetal específicos; em alguns casos, a sua delimitação exigiu um maior detalhamento da compartimentação estabelecida anteriormente (MODENESI 1988a), com subdivisão dos compartimentos em unidades menores e mais simples. As unidadesdiagnóstico são representadas por polígonos que delimitam áreas sob influência de processos semelhantes, característicos de cada uma delas. Por exemplo, os anfiteatros de erosão, representados nos esboços geomorfológicos (Figuras 5, 6 e 7) pela cicatriz dos movimentos de massa (head), correspondem, no diagnóstico, a polígonos que incluem toda a área sob ação de movimentos de massa e concentração do escoamento superficial e subsuperficial, processos característicos dos anfiteatros.

As dez unidades-diagnóstico reconhecidas no vale do Capivari (Figuras 28, 29 e 30) são descritas a seguir.

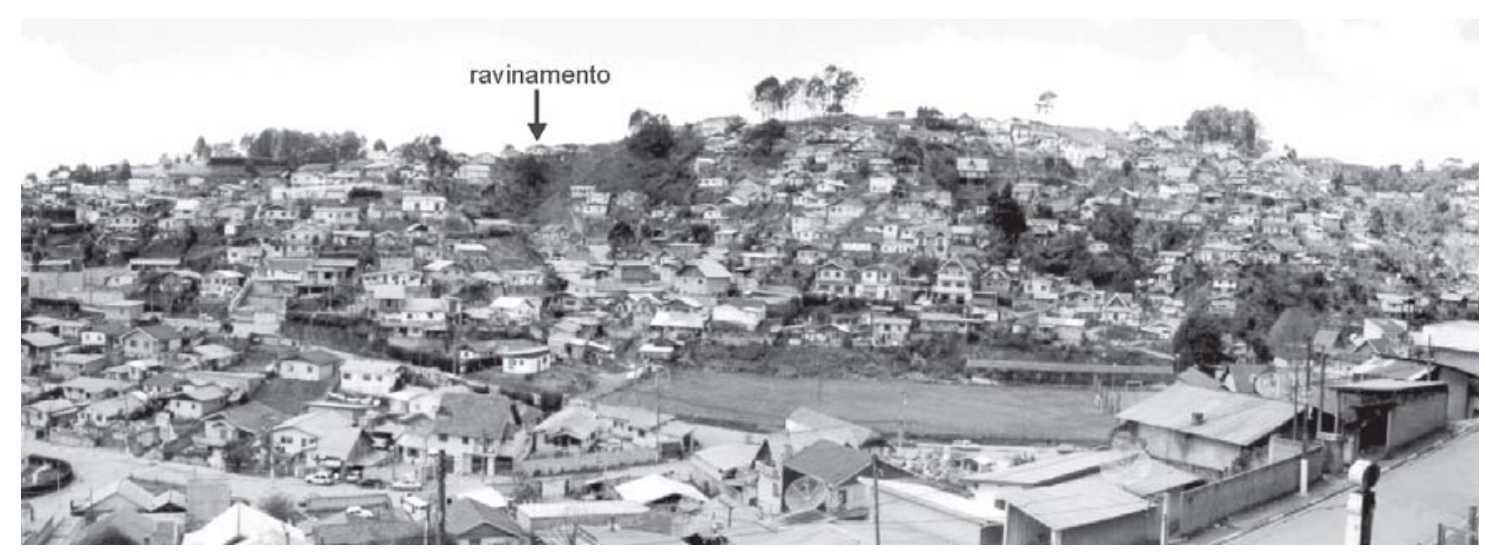

FIGURA 23 - Vila Sodipe, exemplo de ocupação inadequada e densa de vertentes íngremes. No centro da foto, residências de baixo padrão construídas na borda de ravinamento profundo.

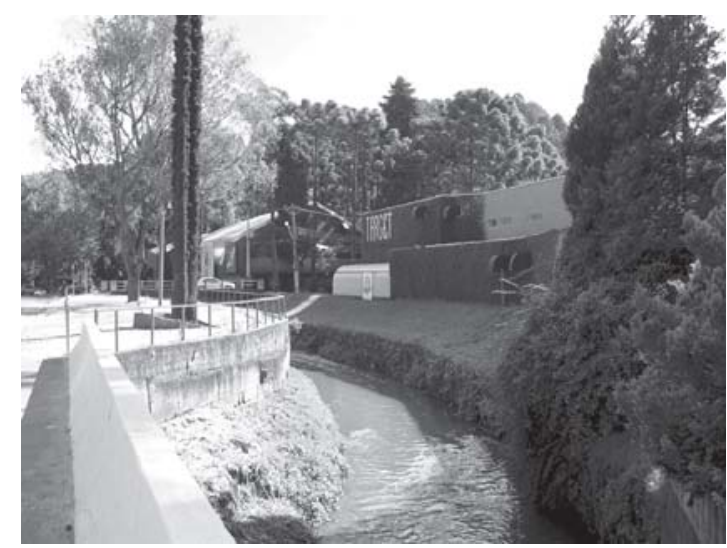

FIGURA 24 - Danceterias construídas na borda do canal do Capivari.

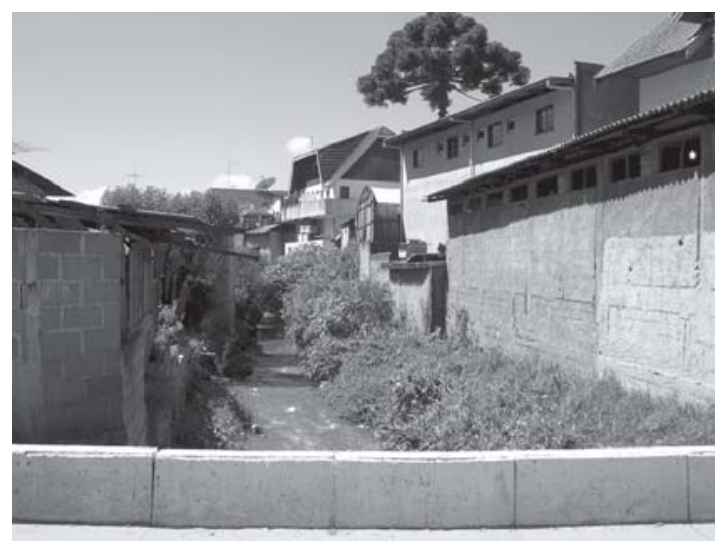

FIGURA 25 - Vários tipos de habitações e estabelecimentos comerciais que ocupam a várzea e avançam sobre o canal do ribeirão Capivari. 
Unidade-diagnóstico 1 - Fazem parte desta unidade as áreas planas do topo dos divisores dos ribeirões e córregos formadores da bacia do SapucaíGuaçu, nivelados a altitudes de 1800/20m, 1710/40m e $1640 / 60 \mathrm{~m}$, e o setor superior das lombas, com declividade geralmente inferior a $8^{\circ}$. Baixa declividade, solos rasos, alteração profunda - rocha alterada coesa e dura, com estruturas preservadas - e ambiente relativamente seco são característicos destas áreas. O processo geomorfológico dominante, relacionado à cobertura por vegetação de campo, é o escoamento superficial de tipo anastomosado, com erosão laminar.

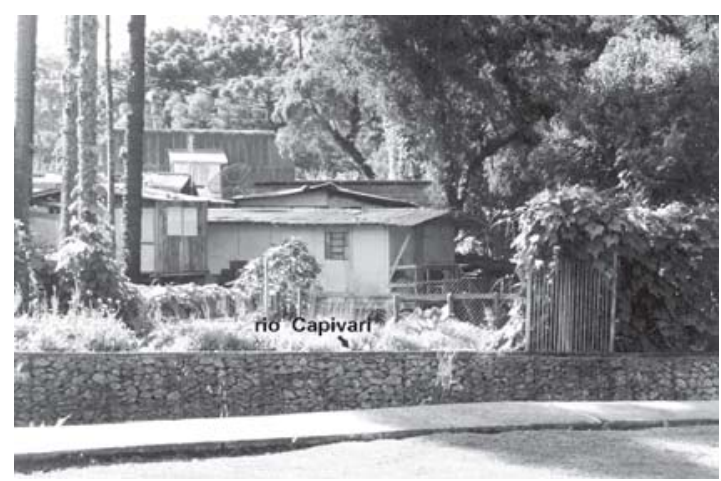

FIGURA 26 - Habitações precárias construídas em Jaguaribe sobre a várzea do Capivari, quase na borda do canal. Alguns dos barracos de madeira já foram substituídos por construções de alvenaria.
Topos de morro e altas lombas são os setores mais estáveis do terreno.

Unidade-diagnóstico 2 - Áreas de vertentes convexas recobertas por campo, as lombas constituem ambiente semelhante ao do topo dos morros, relativamente seco, caracterizado por dispersão do escoamento superficial e subsuperficial, e diferenciado pela maior declividade e menor profundidade do intemperismo e do lençol freático. A presença de solos menos argilosos em superfície reflete a maior intensidade do escoamento pluvial e erosão laminar, relacionados ao aumento da declividade. Acima de $10^{\circ} \mathrm{e}$, principalmente, $15^{\circ}$ há tendência à concentração do escoamento superficial, com aparecimento de filetes e ravinas.

Unidade-diagnóstico 3 - Características próprias do setor inferior das lombas, como perfil retilíneo, declividade acima de $25^{\circ}$ e recobrimento por mata, justificam a criação de um subcompartimento para fins de diagnóstico. Os processos atuantes nesta unidade são semelhantes àqueles das vertentes retilíneas. A mudança de declividade que caracteriza a passagem do setor convexo para o setor retilíneo inferior das lombas é marcada por tendência à concentração do escoamento superficial, expressa na formação de ravinas.

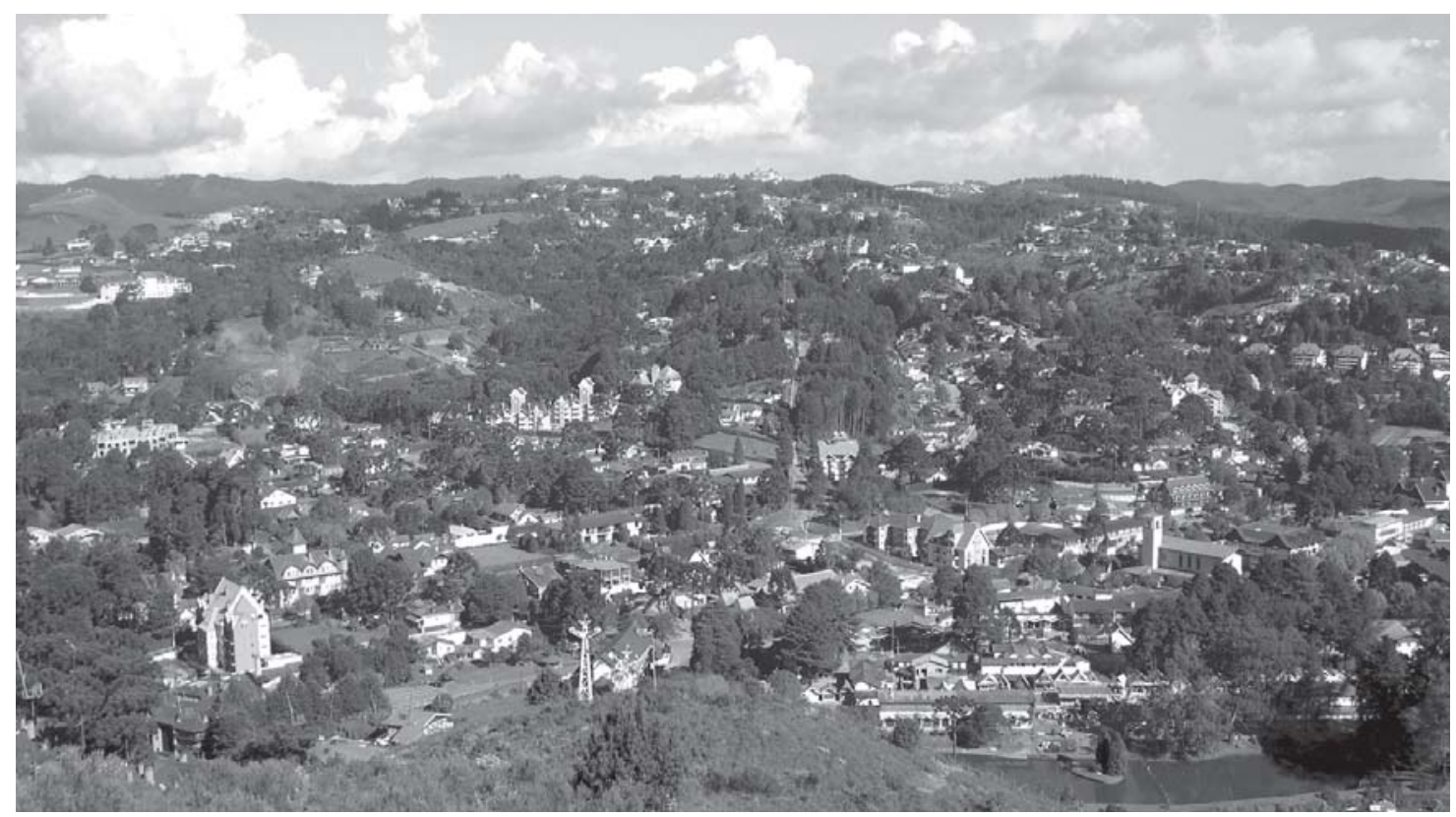

FIGURA 27 - Capivari, na face noroeste do vale de mesmo nome, ocupa principalmente as encostas e topos de 1640/ 60m e 1710/40m (Nova Capivari); na linha do horizonte aparecem dois grandes empreendimentos hoteleiros e um dos condomínios que já ocupam os topos mais elevados (1800/20m). Note-se o padrão de urbanização, com maior preservação das áreas verdes e, nas áreas mais elevadas, do mosaico original de distribuição de mata e campo. 
Unidade-diagnóstico 4 - Vertentes retilíneas são áreas instáveis, essencialmente dinâmicas, onde erosão intensa e acúmulo de colúvios podem originar setores com perfís diferentes, retilíneos ou em patamares. Os setores retilíneos apresentam declividade acentuada, geralmente superior a $25^{\circ} \mathrm{e}$ até $40^{\circ}$, substrato menos alterado, e os solos menos evoluídos do planalto. Forte declividade é o principal fator limitante da ocupação destas áreas, onde a interferência antrópica acelera a ação de processos de erosão linear e movimentos de massa. Mergulhos contrários ao caimento das vertentes, observados principalmente na margem esquerda do ribeirão Capivari, são um fator atenuante da instabilidade característica das vertentes retilíneas; a orientação das vertentes sombrias, por outro lado, agrava a suceptibilidade a movimentos de massa. Nos pequenos patamares formados pela deposição de colúvios, apesar da diminuição da declividade, geralmente inferior a $12^{\circ}$, as condições de estabilidade são comprometidas pelas características dos materiais; sob condições de hidromorfia, grande parte dos colúvios amarelos argilosos ou argilo-sílticos encontra-se em situação de equilíbrio crítico (DE PLOEY et al. 1983).

Unidade-diagnóstico 5 - Os anfiteatros constituem, juntamente com as lombas, as feições mais típicas da paisagem do planalto, principal suporte do mosaico de campo e mata dos altos campos. Caracterizados por alta declividade e convergência do escoamento superficial pluvial, estes compartimentos constituem o sítio preferencial da atividade morfogenética nas encostas, guardando no seu interior evidências da sucessão de eventos de movimentos de massa (escorregamentos profundos, escorregamentos rasos, corridas de terra e lama) e, localmente, de erosão linear que se sucederam durante o Quaternário (MODENESI 1988a, b). Suas características permitem defini-los como unidades altamente instáveis. Registros da recorrência de eventos erosivos pretéritos alertam para o perigo da interferência antrópica; o desmatamento e a ocupação dessas áreas certamente intensificará a ação dos processos erosivos naturais.

Unidade-diagnóstico 6 - Esta unidade inclui as pequenas bacias turfosas da base dos anfiteatros, áreas instáveis, que oferecem elevado potencial de risco à ocupação urbana. A saturação constante das turfas é fator determinante de desequilíbrio e da ocorrência de corridas de lama. Movimentos de massa nas paredes íngremes do interior dos anfiteatros também podem desencadear fenômenos de ero- são violenta nos depósitos turfosos. O desastre ocorrido em Vila Albertina (Figura 5), em 1973, confirma a alta instabilidade dessas áreas. Apesar dos problemas, a baixa declividade tem sido um atrativo para a instalação de loteamentos de renda baixa e média sobre turfeiras. Tentativas de resolver os problemas de ocupação com drenagem e aterramento dos depósitos turfosos não parecem adequadas, uma vez que as camadas de material turfoso permanecem enterradas em locais de concentração do escoamento superficial e subsuperficial, representando um risco potencial.

Unidade-diagnóstico 7 - No vale do Capivari, o maior desenvolvimento das rampas que articulam a base dos anfiteatros com a planície aluvial permite diferenciar uma nova unidade, a das rampas frontais. Essas rampas, com comprimento de 100-300m e declividade de $5-6^{\circ}$ e até $8^{\circ}$, passam às várzeas, sem quebra de declividade; nas áreas densamente urbanizadas, como por exemplo em Abernéssia, é dificil mapeá-las, uma vez que se confundem com a planície aluvial. As rampas frontais dos anfiteatros são áreas de passagem de eventuais fluxos provenientes do interior dos anfiteatros (escoamento superficial, corridas de lama) e podem conter, em alguns casos, material turfoso. Portanto, permanecem nesta unidade as condições desfavoráveis à ocupação que caracterizam anfiteatros e depressões hidromórficas.

Unidade-diagnóstico 8 - Os terraços fluviais do planalto de Campos do Jordão são geralmente pouco extensos e ocorrem recobertos ou retrabalhados por colúvios. Os terraços mais amplos mapeados na margem direita do rio Capivari constituem na realidade um nível resultante do arrasamento das formas e depósitos originais, efetuado para ampliação do sítio favorável, durante o processo de ocupação.

Unidade-diagnóstico 9 - Fazem parte desta unidade as rampas de colúvio, de ocorrência generalizada nas baixas vertentes do planalto; só foram mapeadas aquelas cuja morfologia ocorre preservada, a despeito de modificações introduzidas pela atividade antrópica. O grau de limitação ao uso urbano depende da variação de condições locais como comprimento e declividade das rampas, textura e espessura dos depósitos. Medidas de resistência ao cisalhamento efetuadas em campo (DE PLOEY et al. 1983), nos materiais argilo-síltico amarelados das baixas vertentes 
retilíneas ou das lombas, mostram que grande parte destes sítios, sujeitos à hidromorfia, encontra-se em situação de equilíbrio crítico. Essas condições de instabilidade também caracterizam os depósitos de materiais semelhantes existentes nos patamares das vertentes.

Unidade-diagnóstico 10 - Unidade constituida pelos setores de várzea das pequenas planícies alveolares do ribeirão Capivari e de seus afluentes. Por definição, várzeas são áreas instáveis, sujeitas a inundações. Apesar da característi- ca de rio de planalto do Capivari favorecer o escoamento, inundações localizadas têm ocorrido na área central de Campos do Jordão. A instalação de empreendimentos comerciais e habitações de baixo padrão no interior da várzea dificulta a infiltração e o escoamento das águas pluviais, contribuindo para aumentar a ocorrência de inundações durante a estação chuvosa, principalmente na confluência do Capivari com seus tributários. Alagamentos são também comuns ao longo da avenida principal, nos locais de concentração das enxurra-

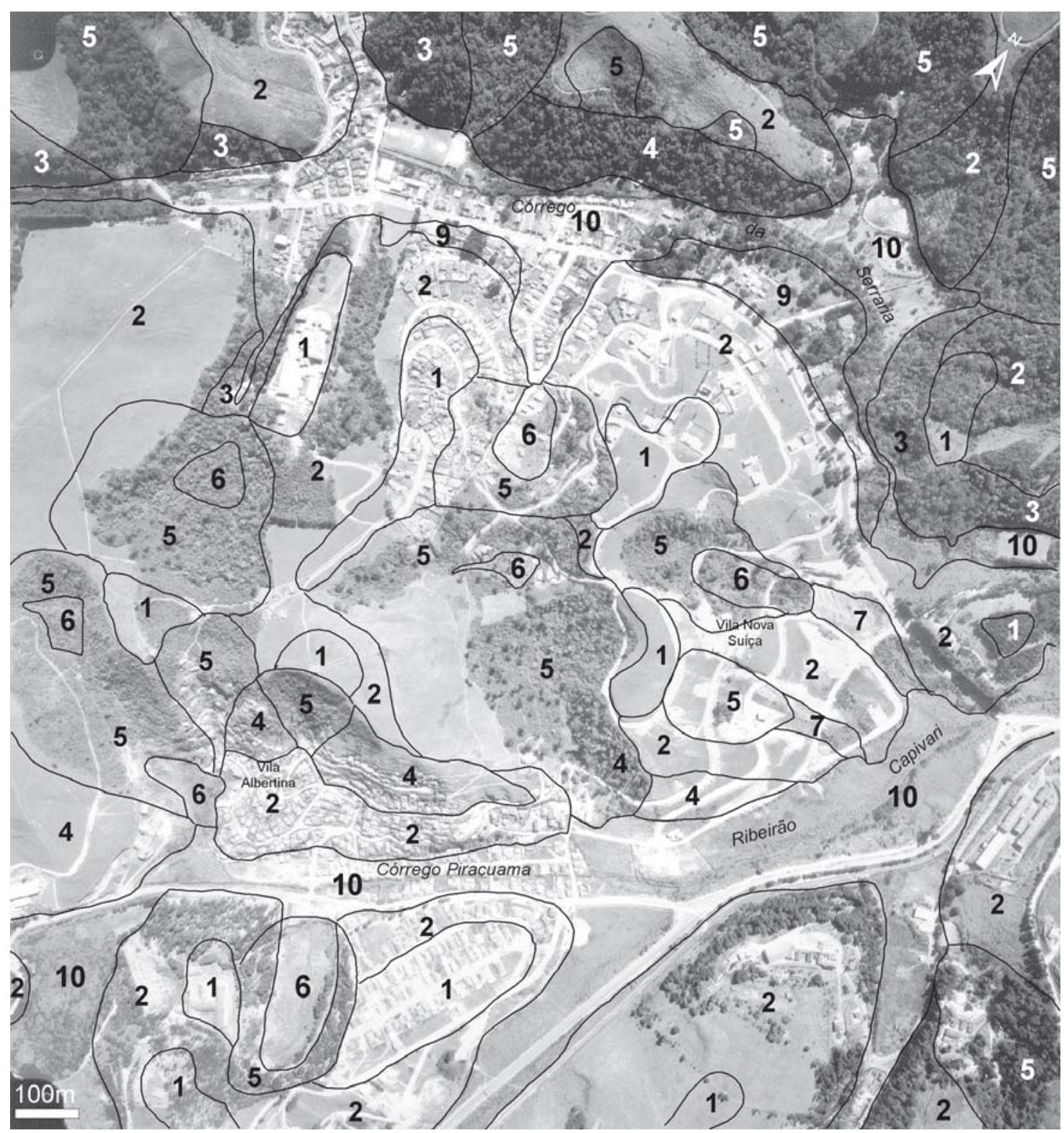

FIGURA 28 - Esboço diagnóstico da área de amostragem A. (1) áreas de topo e setor superior das lombas, (2) lombas propriamente ditas, (3) setor inferior das lombas, (4) vertentes retilíneas, (5) anfiteatros, (6) bacias turfosas, (7) rampas frontais de anfiteatro, (9) rampas de colúvio, (10) várzeas. 
das que descem das áreas mais elevadas por ruas impermeabilizadas.

\section{CLASSIFICAÇÃO GEOMORFOLÓGICA DA APTIDÃO PARA O DESENVOLVIMENTO URBANO}

As dez unidades-diagnóstico definidas no vale do Capivari podem ser agrupadas, conforme o grau de estabilidade e susceptibilidade aos processos erosivos, em três classes com diferentes aptidões para o desenvolvimento urbano (Tabela 1).
Áreas favoráveis à ocupação urbana - incluem as unidades-diagnóstico 1 , 2 e 8 , correspondentes respectivamente ao topo dos morros, lombas propriamente ditas e terraços. Nestas unidades, caracterizadas por menor declividade, predominam processos de erosão laminar; ravinamentos e escorregamentos podem ocorrer apenas nos setores mais íngremes das lombas (> $15^{\circ}$ ). A morfologia e os processos dominantes permitem definir estas áreas como as mais favoráveis, com nenhuma ou pequena limitação à expansão urbana.

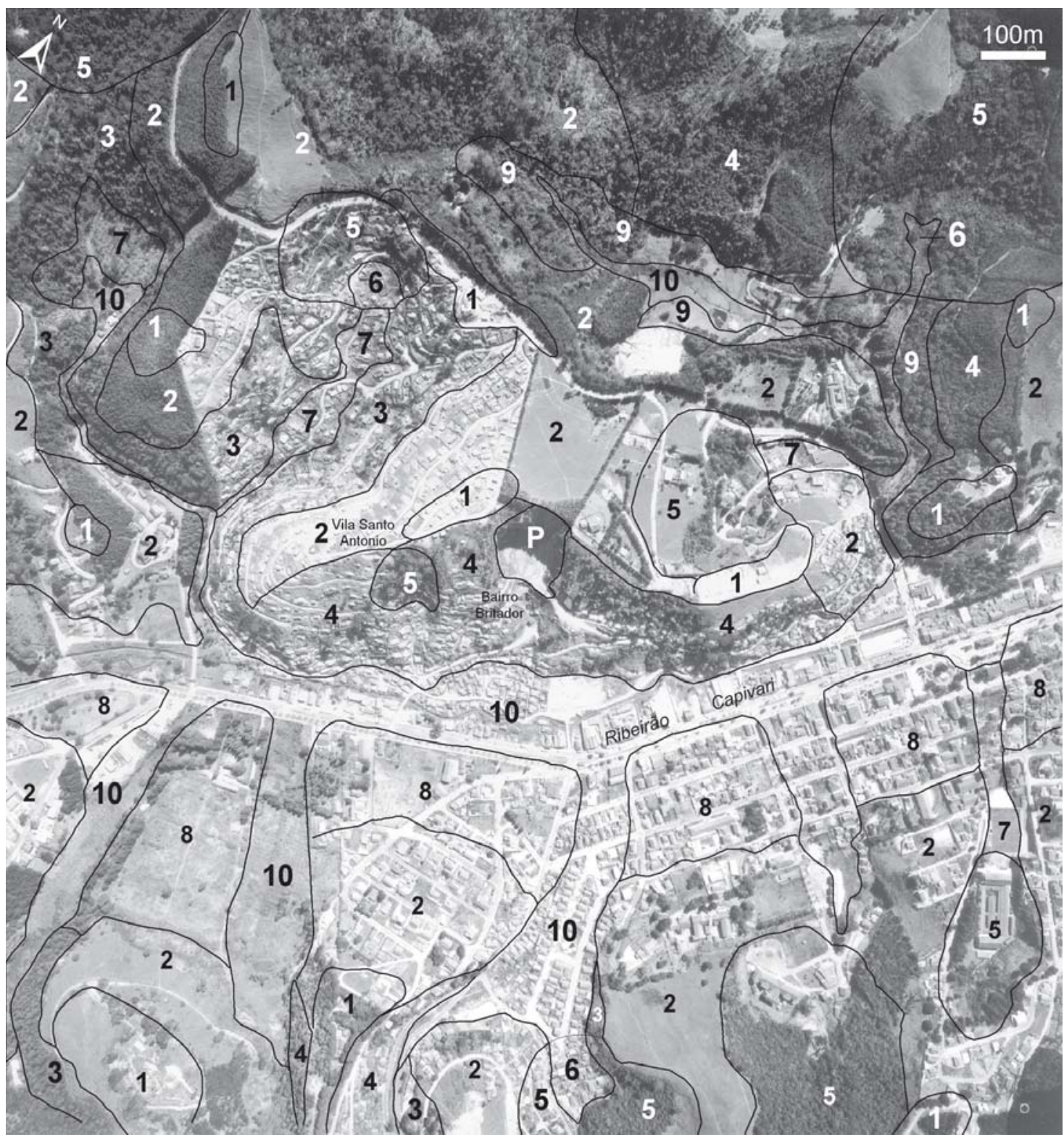

FIGURA 29 - Esboço diagnóstico da área de amostragem B. (1) áreas de topo e setor superior das lombas, (2) lombas propriamente ditas, (3) setor inferior das lombas, (4) vertentes retilíneas, (5) anfiteatros, (6) bacias turfosas, (7) rampas frontais de anfiteatro, (8) baixos terraços fluviais, (9) rampas de colúvio, (10) várzeas. 
Áreas de uso restrito - correspondem às áreas de possivel instabilidade definidas nas unidades-diagnóstico 7 e 9, respectivamente, rampas frontais dos anfiteatros e rampas de colúvio. Estas são áreas de baixa declividade, que atraem a ocupação; entretanto, sua localização na saída dos anfiteatros e no sopé das vertentes, respectivamente, torna-as vulneráveis à ação de processos erosivos e à deposição de sedimentos, caso ocorram desequilíbrios a montante.

Áreas de preservação - incluem as unidades instáveis caracterizadas por alta declividade, 3, 4 e
5, presença de materias turfosos, 6 , ou por sua posição no interior da planície de inundação, 10. O setor inferior das lombas (3) é, por sua história e condição geomorfológica, área de deposição de colúvios (depósitos das rampas de colúvio). Atualmente estável, e nas condições naturais revestido por mata, este setor das vertentes pode ser desestabilizado pela interferência antrópica, desencadeando ravinamentos e pequenos movimentos de massa. As unidades 4 (vertentes retilíneas) e 5 (anfiteatros) apresentam condições locais favoráveis à ação de movimentos de massa - em geral,

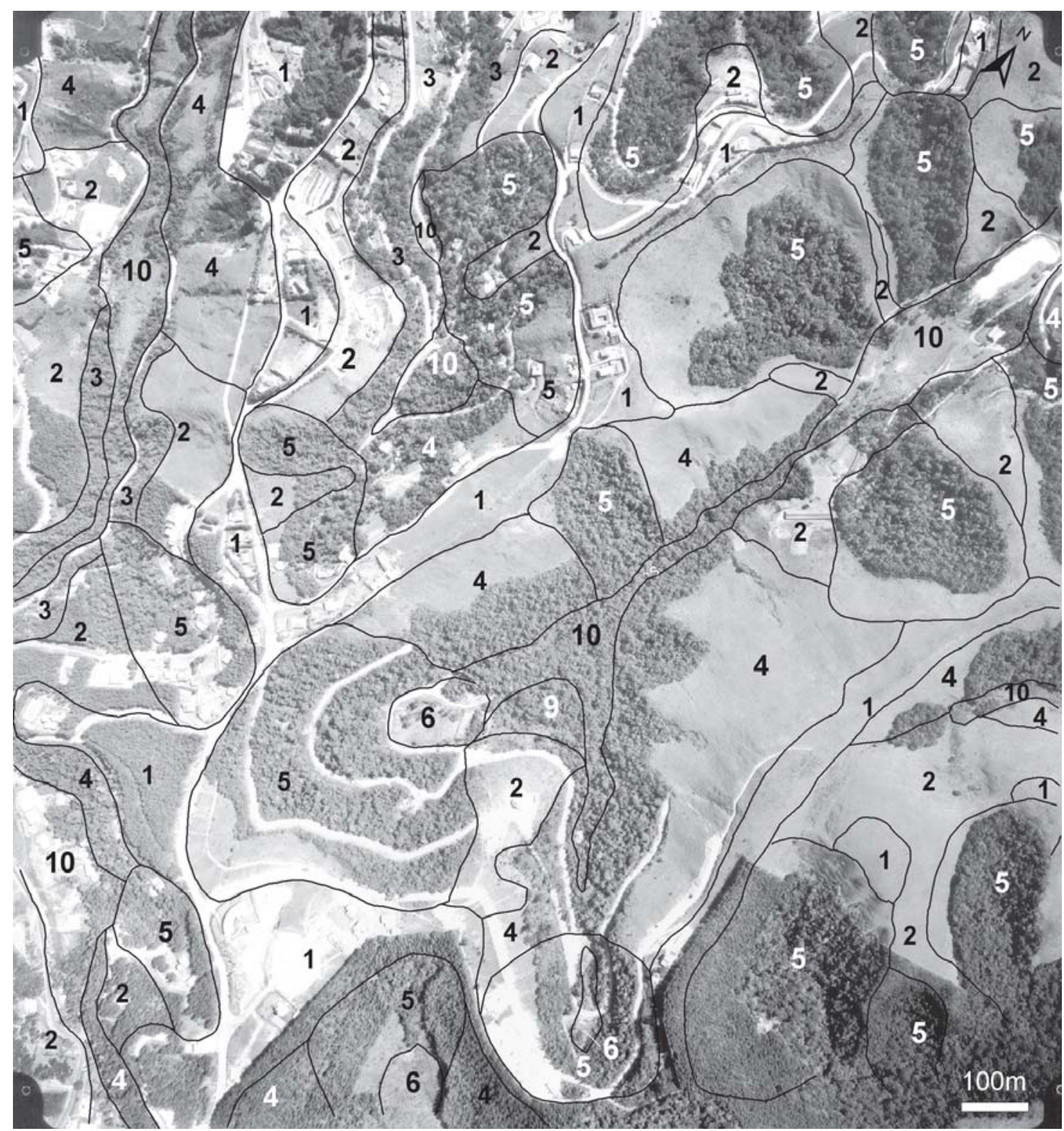

FIGURA 30 - Esboço diagnóstico da área de amostragem C. (1) áreas de topo e setor superior das lombas, (2) lombas propriamente ditas, (3) setor inferior das lombas, (4) vertentes retilíneas, (5) anfiteatros, (6) bacias turfosas, (10) várzeas. 
escorregamentos nas vertentes retilíneas e escorregamentos, slumps e corridas de terra ou lama nos anfiteatros - e à formação de ravinas, principalmente quando seu equilíbrio é modificado pela interferência antrópica (desmatamento, cortes e construções). Evidências de eventos recorrentes de movimentos de massa durante o Quaternário (escorregamentos profundos, escorregamentos rasos e corridas de terra e lama) confirmam esta tendência evolutiva nas vertentes retilíneas e, principalmente, nos anfiteatros. A unidade 6 corresponde às pequenas bacias da base dos anfiteatros, onde condições de hidromorfia e presença de espessas camadas de turfa tropical são responsáveis pela incidência de corridas de lama. As reduzidas e estreitas várzeas (10) intercaladas entre trechos encaixados do ribeirão Capivari estão sujeitas a inundações localizadas, agravadas pela crescente impermeabilização do solo e pelos obstáculos criados no interior da planície de inundação por cons- truções abusivas, que aumentam o volume e retardam o escoamento das águas pluviais.

\section{CONSIDERAÇÕES FINAIS}

Nos altos campos do Jordão, a ação dos processos atuais soma-se à herança quaternária (MODENESI 1988a, b) na definição de uma paisagem em equilíbrio precário. As condições naturais de instabilidade existentes no planalto têm sido agravadas nas últimas décadas pelo desmatamento progressivo e pelo impacto do crescimento desordenado dos três núcleos urbanos da estância climática de Campos do Jordão: Abernéssia, Jaguaribe e Capivari. Adoção de técnicas inadequadas de construção (corte e aterro) (Figura 22), assim como infraestrutura deficiente (esgoto, escoamento de águas pluviais) modificaram a natureza e intensidade dos processos hidrológicos e geomorfológicos, aumentando as condições de risco nas vertentes. Neste contexto, o conhecimento das

TABELA 1- Classificação geomorfológica da aptidão para o desenvolvimento urbano

\begin{tabular}{|c|c|c|c|c|c|}
\hline 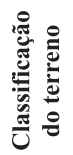 & $\begin{array}{l}\text { Condições de } \\
\text { estabilidade. } \\
\text { Limitações }\end{array}$ & $\begin{array}{l}\text { Unidade - } \\
\text { diagnóstico }\end{array}$ & $\begin{array}{l}\text { Compartimento } \\
\text { geomorfológico }\end{array}$ & Vegetação & Processos dominantes \\
\hline \multirow{3}{*}{ 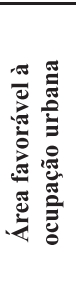 } & $\begin{array}{l}\text { área estável, com } \\
\text { nenhuma ou pequena } \\
\text { limitação para } \\
\text { instalações urbanas }\end{array}$ & 1 & $\begin{array}{l}\text { topo de morro, } 0 \text { a } 2^{\circ} ; \\
\text { setor superior de lomba, } \\
5 \text { a } 8^{\circ}\end{array}$ & campo & $\begin{array}{l}\text { escoamento superficial anastomosado } \\
\text { com erosão laminar; com o aumento da } \\
\text { declividade, tendência à concentração } \\
\text { em filetes (rills) }\end{array}$ \\
\hline & $\begin{array}{l}\text { área estável, com } \\
\text { limitações à ocupação } \\
\text { dos setores mais } \\
\text { íngremes das lombas }\end{array}$ & 2 & $\begin{array}{l}\text { lombas propriamente } \\
\text { ditas, } 12-15 \text { até } 20^{\circ}\end{array}$ & campo & $\begin{array}{l}\text { predomínio da erosão laminar; acima } \\
\text { de } 10^{\circ} \text {, e principalmente } 15^{\circ} \text {, } \\
\text { vulnerável a ravinamentos (gullies) e } \\
\text { escorregamentos }\end{array}$ \\
\hline & $\begin{array}{l}\text { área estável, favorável a } \\
\text { instações urbanas }\end{array}$ & 8 & $\begin{array}{l}\text { baixo terraço; terraço } \\
\text { arrasado }\end{array}$ & mata & erosão laminar fraca \\
\hline \multirow{2}{*}{ 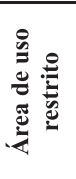 } & $\begin{array}{l}\text { área de instabilidade } \\
\text { possível, com limitações } \\
\text { moderadas à ocupação }\end{array}$ & 7 & $\begin{array}{l}\text { rampa frontal de } \\
\text { anfiteatro; } 5-6 \text { até } 8^{\circ}\end{array}$ & $\begin{array}{l}\text { vegetação } \\
\text { herbácea }\end{array}$ & $\begin{array}{l}\text { por sua posição geomorfológica, } \\
\text { vulnerável a ações de escoamento } \\
\text { superficial intenso e corridas de lama }\end{array}$ \\
\hline & $\begin{array}{l}\text { área de instabilidade } \\
\text { possível, com limitações } \\
\text { moderadas à ocupação }\end{array}$ & 9 & $\begin{array}{l}\text { rampa de colúvio; } 6 \text { a } \\
8^{\circ}\end{array}$ & mata & $\begin{array}{l}\text { pelas características dos materiais, em } \\
\text { condições de hidromorfia é vulnerável } \\
\text { a escorregamentos }\end{array}$ \\
\hline \multirow{5}{*}{ 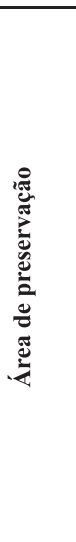 } & $\begin{array}{l}\text { área de instabilidade } \\
\text { possível, com limitações } \\
\text { à ocupação }\end{array}$ & 3 & $\begin{array}{l}\text { setor retilíneo inferior } \\
\text { de lomba; superior a } \\
25^{\circ}\end{array}$ & mata & $\begin{array}{l}\text { ação de ravinamentos e pequenos } \\
\text { movimentos de massa, acelerada pela } \\
\text { interferência antrópica (desmatamento) }\end{array}$ \\
\hline & $\begin{array}{l}\text { área instável, com graves } \\
\text { limitações à ocupação }\end{array}$ & 4 & $\begin{array}{l}\text { vertente retilínea; } 25 \text { a } \\
40^{\circ}\end{array}$ & mata & $\begin{array}{l}\text { declividade alta favorece a ação de } \\
\text { processos de ravinamento e } \\
\text { movimentos de massa }\end{array}$ \\
\hline & $\begin{array}{l}\text { área altamente instável, } \\
\text { com graves limitações à } \\
\text { ocupação }\end{array}$ & 5 & $\begin{array}{l}\text { anfiteatro de erosão; } 23 \\
\text { a } 45^{\circ}\end{array}$ & mata & $\begin{array}{l}\text { alta declividade e convergência do } \\
\text { escoamento superficial e subsuperficial } \\
\text { determinam grande vulnerabilidade à } \\
\text { ação de movimentos de massa rasos } \\
\text { (planar slides), escorregamentos } \\
\text { rotacionais (slump slides) e } \\
\text { ravinamentos }\end{array}$ \\
\hline & $\begin{array}{l}\text { área instável, com graves } \\
\text { limitações à ocupação }\end{array}$ & 6 & $\begin{array}{l}\text { depressão turfosa; } 2 \text { a } \\
3^{\circ}\end{array}$ & turfeira & $\begin{array}{l}\text { características dos materiais e } \\
\text { condições de hidromorfia favorecem o } \\
\text { desencadeamento de corridas de lama }\end{array}$ \\
\hline & $\begin{array}{l}\text { área instável, com graves } \\
\text { limitações à ocupação }\end{array}$ & 10 & várzea; $0^{\circ}$ & $\begin{array}{l}\text { vegetação } \\
\text { herbácea }\end{array}$ & inundações localizadas \\
\hline
\end{tabular}


características físicas do terreno e dos processos geomorfológicos dominantes adquire especial significado para o planejamento urbano.

A análise geomorfológica, associada à observação das modificações provocadas pela urbanização no vale do ribeirão Capivari, forneceu os elementos necessários para identificar áreas problemáticas e melhor adequar a expansão urbana às condições locais do sítio. A compartimentação geomorfológica do planalto, marcada por fortes contrastes fisionômicos e ambientais e pelo mosaico da vegetação, mostrou ser base segura e de fácil percepção para delimitar áreas favoráveis ou desfavoráveis à ocupação. O diagnóstico efetuado permitiu definir unidades com diferentes graus de suscetibilidade aos processos erosivos e, considerando seu risco potencial, indicar as que merecem preservação total (anfiteatros de erosão, vertentes retilíneas, depressões turfosas e planícies alveolares) e as mais adequadas à ocupação (topos, lombas de baixa declividade e terraços). Esses resultados são válidos para orientar a expansão urbana em todas as áreas de altos campos do planalto (Figura 4).

A forte pressão exercida pela expansão urbana no planalto determinou a invasão das áreas de maior potencial de risco geomorfológico: vertentes retilíneas, anfiteatros, depressões turfosas e várzeas. A declividade acentuada que caracteriza os dois primeiros é por si só evidência de condições de instabilidade, comprovadas pelos depósitos de movimentos de massa recorrentes, principalmente nos anfiteatros; a ocupação dessas áreas é, certamente, problemática. Nas vertentes íngremes da margem esquerda do ribeirão Capivari, o bairro Britador (Figura 21) é exemplo da situação de risco em que se encontram as populações de baixo poder aquisitivo instaladas nestes sítios, onde a instabilidade das vertentes retilíneas, naturalmente sujeitas a processos de escorregamento, é agravada pelo uso de técnicas de construção inadequadas; na estação chuvosa de 2000, escorregamentos múltiplos destruiram mais de 300 das 400 casas ali construídas. Em Vila Santo Antônio, casas de padrão inferior ocupam vertentes de declividade superior a $35^{\circ}$ (Figura 14). É também comum a ocupação de encostas com declividades de até $30^{\circ}$ por residências de padrão médio, caso de Vila Sodipe (Figura 23). As crescentes demandas da urbanização levaram ainda à ocupação das depressões turfosas, áreas de topografia favorável porém sujeitas a processos de corrida de lama, semelhantes aos que provocaram o desastre de Vila Albertina, em 1972. Apesar dos problemas, a ocupação de áreas impróprias continua a se fazer de forma regular, até mesmo por loteamentos. Por exemplo, em Vila Nova Suíça, na base do anfiteatro cortado pela rua Davos (Figura 16), residências foram construidas sobre depósitos turfosos tamponados por camada pouco espessa de materiais provenientes das encostas. A ocupação das várzeas é hoje quase total, com construções feitas praticamente no talvegue do rio (Figuras 24, 25 e 26).

Um sinal evidente de deterioração da paisagem é a descaracterização do mosaico de mata e campo típico dos altos campos do planalto, que vem sendo alterado, primeiro, pelo plantio de Pinus elliottii nas áreas de campo, topos e lombas, e, em segundo lugar, pela ocupação da borda das matas (Figura 31). Este último é um processo que leva ao desmatamento progressivo, com recuo do contato

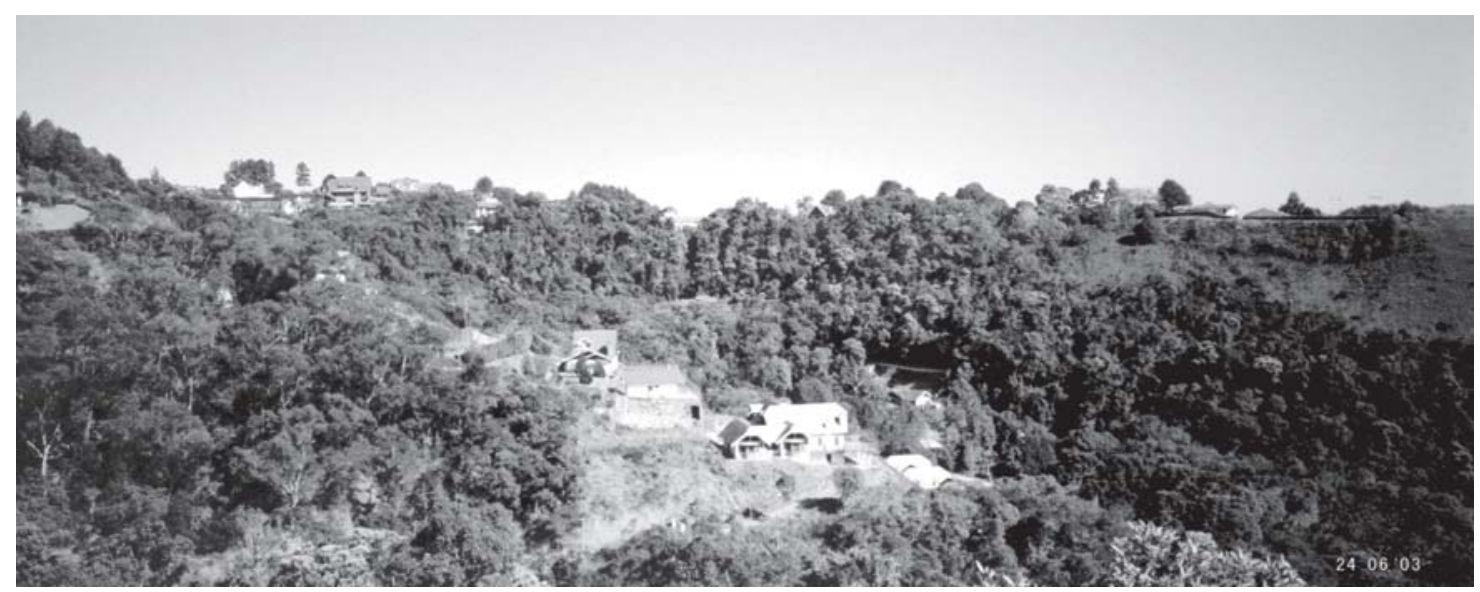

FIGURA 31 - Evidência do processo de desmatamento progressivo que ocorre na borda das matas, por instalações localizadas inicialmente em áreas de campo, com recuo do limite mata/campo. 
campo/mata, como pode ser observado na Estrada Velha do Itapeva, onde a instalação de grandes empreendimentos hoteleiros e condomínios no topo dos morros provocou destruição ou rarefação das matas dos anfiteatros próximos.

A interferência humana nas condições de equilíbrio das encostas aumentou a vulnerabilidade da paisagem aos desastres ambientais, que ocorrem principalmente sob condições extremas de pluviosidade. Qualquer tentativa de planejamento urbano do planalto não poderá deixar de considerar estes fatos, para diminuir as conseqüências da degradação ambiental e evitar a repetição de situações de alto risco. Apesar de constituir em sua quase totalidade área de preservação ambiental, o planalto de Campos do Jordão vem sofrendo o constante impacto de um processo acelerado de urbanização, com consequiências graves no aumento dos problemas ambientais e na degradação da paisagem. Considerando-se sua posição na serra da Mantiqueira, importante divisor de águas das bacias do Paraíba do Sul e Paraná, estes fatos são especialmente preocupantes.

\section{AGRADECIMENTOS}

Os autores agradecem ao Engenheiro Agrônomo Alexandre Gonçalves da Silva, na ocasião Secretário do Meio Ambiente do Município de Campos do Jordão, pelo apoio logístico e fornecimento de documentos cartográficos; ao Instituto de Pesquisas Tecnológicas/São Paulo, a cessão da Folha Campos do Jordão I (digitalizada); aos consultores da revista, a revisão crítica.

\section{REFERÊNCIAS BIBLIOGRÁFICAS}

ALMEIDA, F.F.M. 1976. The system of continental rifts bordering the Santos Basin, Brazil. In: Anais Academia Brasileira de Ciências, CONTINENTAL MARGINS OF ATLANTIC TYPE, São Paulo, 1975, 48 (Suplemento): 15-26.

AB'SÁBER, A.N. 1966. O domínio morfoclimático dos mares de morros no Brasil. São Paulo, USP, Instituto de Geografia, 9p. (Geomorfologia, 2).

BERTRAND, G. 1968. Paysage et géographie physique globale: esquise méthodologique. Révue Géographique Pyrenées et Sud-ouest, 39(3):249-262.
CAVALCANTE, J.C. et alii. 1979. Projeto Sapucaí Estados de Minas Gerais e São Paulo. Relatório Final de Geologia. Brasília, DNPM/CPRM, 299 p. (Série Geologia 5, Seção Geologia Básica 2).

COMISSÃO NACIONAL DE SOLOS. 1960. Levantamento de reconhecimento dos solos do Estado de São Paulo. Rio de Janeiro, Ministério da Agricultura SNPA, 634 p. (Boletim Técnico, 12).

CONTI, J.B. 1975. Circulação secundária e efeito orográfico na gênese das chuvas na região lesnordeste paulista. São Paulo, USP, Instituto de Geografia, 82 p. (Série Teses e Monografias, 18).

DE PLOEY, J.; CRUZ, O.; MODENESI, M.C. 1983. Résistances au cisaillement et conditions de glissements de terrain à Caraguatatuba et à Campos do Jordão (État de São Paulo). In: COLÓQUIOINTERDISCIPLINARFRANCO-BRASILEIRO Estudo e Cartografação de Formações Superficiais e Suas Aplicações em Regiões Tropicais, São Paulo, 1978, Anais, l:393- 402.

HART, M.G. 1986. Geomorphology, pure and applied. Allen \& Unwin (Publishers) Ltd., London, 228 p.

HASUI, Y. \& OLIVEIRA, M.A.F. 1984. A Província Mantiqueira - Setor Central. In: F.F.M. Almeida \& Y. Hasui (ed.) O Pré-Cambriano do Brasil. São Paulo, Edgard Blücher, 378 p.

HASUI, Y. et alii. 1978. Geologia da Região Administrativa 3 (Vale do Paraíba) e parte da Região Administrativa 2 (Litoral) do Estado de São Paulo. São Paulo: Instituto de Pesquisas Tecnológicas, 78 p. (Publicação 1106).

HIRUMA, S.T. 1999. Neotectônica no Planalto de Campos do Jordão, São Paulo. Instituto de Geociências, Universidade de São Paulo, São Paulo, Dissertação de Mestrado, 102 p.

HIRUMA, S.T.; RICCOMINI, C.; MODENESIGAUTTIERI, M.C. 2001. Neotectônica no Planalto de Campos do Jordão, SP. São Paulo: Revista Brasileira de Geociências, 31(3): 375-384.

MODENESI, M.C. 1980. Intemperismo e morfogênese no planalto de Campos do Jordão. Revista Brasileira de Geociências, 10(3):213 - 225. 
MODENESI, M.C. 1983. Weathering and morphogenesis in a tropical plateau. Catena, 10 (3):237-251.

MODENESI, M.C. 1988a. Significado dos depósitos correlativos quaternários em Campos do Jordão - São Paulo: implicações paleoclimáticas e paleoecológicas. São Paulo: Instituto Geológico, 155p. (Boletim 7).

MODENESI, M.C. 1988b. Quaternary mass movements in a tropical plateau (Campos do Jordão, São Paulo, Brazil). Zeitschrift für Geomorphologie N.F., 32(4): 425-440.

MODENESI, M.C. 1992. Depósitos de vertente e evolução quaternária do planalto do Itatiaia RJ. Revista do Instituto Geológico, 13(1): 3l-46.

MODENESI, M.C. \& JORDÃO, S. 1992. A erosão acelerada em Caçapava. São Paulo: Instituto Geológico, 3l p. e carta de erosão 1:10.000 (Boletim 9).

MODENESI, M.C.; MATSUI, E.; VOLKOFF, B. 1982. Relação 13C/12C nos horizontes húmicos superficiais e nos horizontes escuros profundos dos solos de campo e mata da região de Campos do Jordão, São Paulo, Brasil. In: CENA USP, PROMOCET, COLÓQUIO REGIONAL SOBREAMATÉRIAORGÂNICADOS SOLOS, Anais, p. 155-160.

MODENESI, M.C. \& MELHEM, T.S. 1992 . Palynological data on a Holocene peat deposit in tropical Brasil. São Paulo: Revista do Instituto Geológico, 13(2): 7-15.

MODENESI, M.C. \& TOLEDO, M.C.M. 1993. Morfogênese quaternária e intemperismo: colúvios do planalto do Itatiaia. São Paulo: Revista do Instituto Geológico 14(1): 45 -53.

MODENESI-GAUTTIERI, M.C. 1996. As cimeiras diferenciadas da Mantiqueira, dos Campos do Jordão ao Maciço do Itatiaia. Colúvios das baixas vertentes. Uberlândia: Revista Sociedade e Natureza, 3(15): 45-50.

MODENESI-GAUTTIERI, M. C. \& TOLEDO, M.C.M. 1996. Weathering and the formation of hillslope deposits in the tropical highlands of Itatiaia. Catena, 27(3): 81-103.
MODENESI-GAUTTIERI, M.C. 2000. Hillslope deposits and the Quaternary evolution of the altos campos - Serra da Mantiqueira, from Campos do Jordão to the Itatiaia Massif. In: IGS, INTERNATIONAL GEOLOGICAL CONGRESS, 31, Rio de Janeiro, Brasil. Revista Brasileira de Geociências, 30(3): 504510.

MODENESI-GAUTTIERI, M.C.; HIRUMA, S.T.; RICCOMINI, C. 2002. Morphotectonics of a high plateau on the northwestern flank of the Continental Rift of southeastern Brazil. Geomorphology, 43: 257-271.

MODENESI-GAUTTIERI, M.C. \& NUNES, L. H. 1998. Processos geocriogênicos quaternários nas cimeiras da Mantiqueira, com considerações climáticas. São Paulo: Revista do Instituto Geológico, 19(1/2):19-30.

MOEYERSONS, J. 1989. La nature de l'érosion des versants au Rwanda. Tervuren: Annales Sciences Économiques, 19: 389 p.

MONTEIRO, C.A. 1964. Sobre um índice de participação das massas de ar e suas possibilidades de aplicação à classificação climática. Rio de Janeiro: Revista Geográfica, 33(61): 5969.

MONTEIRO, C.A. 1969. A frente polar atlântica e as chuvas de inverno na fachada sul oriental do Brasil: contribuição metodológica à análise rítmica dos tipos de tempo no Brasil. São Paulo, USP, Instituto de Geografia, 68 p. (Série Teses e Monografias, 1).

MORAIS, S.M.; DEHLER, N.M.; SACHS, L.L.B.; RODRIGUES, J.B. 1998. Carta geológica - Folha Guaratinguetá(SF.23-Y-B), escala 1:250.000. São Paulo, CPRM - Superintendência Regional de São Paulo, Programa Levantamentos Geológicos Básicos do Brasil.

MORGAN, R.P.C. 1986. Soil erosion \& conservation. London, Longman Scientific and Technical, $289 \mathrm{p}$.

OLIVEIRA, J.B.; MENK, J.F.R.; ROTTA, C.C. 1975. Solos do Parque Estadual de Campos do Jordão. São Paulo: Revista do Instituto Florestal, 9: 125-155. 
SIEBERT, P. et alii. 1975. Plano de manejo do Parque Estadual de Campos do Jordão. São Paulo: Instituto Florestal, 148p. (Boletim Técnico, 19).

SILVA, A. G. 2002. Educação ambiental como instrumento na mitigação de riscos frente à ocupação de encostas no município de Campos do Jordão - SP. Projeto de pesquisa de mestrado, Universidade de Taubaté, Programa de Pósgraduação em Engenharia Ambiental (datilografado).
TRICART, J. 1965. Principes et Méthodes de la Géomorphologie. Masson \& Cie. Editeurs, Paris, $496 \mathrm{p}$.

VERSTAPPEN, H.TH. 1983. Applied Geomorphology: geomorphological surveys for environmental development. Elsevier, Amsterdam, 437 p.

\section{Endereço dos autores:}

May Christine Modenesi-Gauttieri - Instituto Geológico, Secretaria do Meio Ambiente, Avenida Miguel Stéfano, 3900, CEP 04301-903, Água Funda, São Paulo, SP. E-mail: modenesi@igeologico.sp.gov.br

Silvio Takashi Hiruma - Instituto Geológico, Secretaria do Meio Ambiente, Avenida Miguel Stéfano, 3900, CEP 04301-903, Água Funda, São Paulo, SP. E-mail: hiruma@igeologico.sp.gov.br 